\title{
Metal complexes in cancer therapy - an update from drug design perspective
}

\author{
This article was published in the following Dove Press journal: \\ Drug Design, Development and Therapy \\ 3 March 2017 \\ Number of times this article has been viewed
}

\section{Umar Ndagi \\ Ndumiso Mhlongo \\ Mahmoud E Soliman}

Molecular Modelling and Drug Design Research Group, School of Health Sciences, University of KwaZuluNatal, Westville, Durban, South Africa
Correspondence: Mahmoud E Soliman Molecular Modelling and Drug Design Research Group, School of Health Sciences, University of KwaZulu-Natal, Westville, Durban 4000, South Africa

Tel +27312607413

$\mathrm{Fax}+2731260779$

Email soliman@ukzn.ac.za
Abstract: In the past, metal-based compounds were widely used in the treatment of disease conditions, but the lack of clear distinction between the therapeutic and toxic doses was a major challenge. With the discovery of cisplatin by Barnett Rosenberg in 1960, a milestone in the history of metal-based compounds used in the treatment of cancers was witnessed. This forms the foundation for the modern era of the metal-based anticancer drugs. Platinum drugs, such as cisplatin, carboplatin and oxaliplatin, are the mainstay of the metal-based compounds in the treatment of cancer, but the delay in the therapeutic accomplishment of other metal-based compounds hampered the progress of research in this field. Recently, however, there has been an upsurge of activities relying on the structural information, aimed at improving and developing other forms of metal-based compounds and nonclassical platinum complexes whose mechanism of action is distinct from known drugs such as cisplatin. In line with this, many more metal-based compounds have been synthesized by redesigning the existing chemical structure through ligand substitution or building the entire new compound with enhanced safety and cytotoxic profile. However, because of increased emphasis on the clinical relevance of metal-based complexes, a few of these drugs are currently on clinical trial and many more are awaiting ethical approval to join the trial. In this review, we seek to give an overview of previous reviews on the cytotoxic effect of metal-based complexes while focusing more on newly designed metal-based complexes and their cytotoxic effect on the cancer cell lines, as well as on new approach to metal-based drug design and molecular target in cancer therapy. We are optimistic that the concept of selective targeting remains the hope of the future in developing therapeutics that would selectively target cancer cells and leave healthy cells unharmed.

Keywords: cancer, DNA, platinum, metal complexes, apoptosis, selective target

\section{Introduction}

Therapeutic potentials of metal-based compounds date back to ancient time. ${ }^{1}$ During this period, the ancient Assyrians, Egyptians and Chinese knew about the importance of using metal-based compounds in the treatment of diseases, ${ }^{1}$ such as the use of cinnabar (mercury sulfide) in the treatment of ailments. ${ }^{1}$ The advent of "theoretical science", by Greek philosophers (Empedocles and Aristotle) in the 5th and 4th century BC, ${ }^{1}$ boosted the knowledge of metal-based compounds as therapeutic agents. This was supported by the information handed down by Pliny and Aulus Cornelius Celsus (Roman physicians) on the use of cinnabar in the treatment of trachoma and venereal diseases. ${ }^{1}$ In the 9 th and 11 th century $\mathrm{BC}$, the contributions of ancient scientists such as Rhazes (Al-Razi) and Avicenna (Ibn Sina) were applauded, ${ }^{1}$ sequel to the discovery of toxicological effects of mercury in the animals and the use of mercury (quicksilver ointment) for skin diseases respectively. 
Arsenic trioxide (ATO) was used as an antiseptic ${ }^{2}$ and in the treatment of rheumatoid diseases, syphilis and psoriasis by traditional Chinese medical practitioners. ${ }^{2}$ Certainly, ATO was among the first compounds suggested for use in the treatment of leukemia ${ }^{3}$ during 18th and 19th centuries, until in the early 20th century when its use was replaced by radiation and cytotoxic chemotherapy. ${ }^{3}$ Therapeutic use of gold and copper can be traced to the history of civilization, ${ }^{4}$ where the Egyptians and Chinese were famous users in the treatment of certain disease conditions, such as syphilis. ${ }^{4}$ The discovery of platinum compound (cisplatin) by Barnett Rosenberg in $1960 \mathrm{~s}^{5}$ was a milestone in the history of metal-based compounds used in the treatment of cancer. ${ }^{6}$ This forms the foundation for the modern era of the metalbased anticancer drug. ${ }^{5}$ Despite the wide use of the metalbased compounds, the lack of clear distinction between the therapeutic and toxic doses was a major challenge. This was so because practitioners of ancient time lack adequate knowledge of dose-related biological response. ${ }^{7}$ The advent of molecular biology and combinatorial chemistry paves the way for the rational design of chemical compounds to target specific molecules. ${ }^{7}$

Generally, metals are essential components of cells chosen by nature. ${ }^{8}$ They are frequently found in the enzyme catalytic domain ${ }^{9}$ and are involved in multiple biological processes, from the exchange of electrons to catalysis and structural roles. ${ }^{9}$ They are extensively used in cellular activities. ${ }^{9}$ Such metals include gallium, zinc, cobalt, silver, vanadium, strontium, manganese and copper, which are required in trace amounts to trigger catalytic processes. ${ }^{10}$ To this end, a balance between cellular need and the amount available in the body is important for the normal physiological state. Comparatively, metals, including nickel, cadmium, chromium and arsenic, can induce carcinogenesis and hence are less beneficial to the body..$^{10}$ These limitations have triggered a search for platinum-based compounds that show lower toxicity, higher selectivity and a broader spectrum of activity. ${ }^{8,11,12}$ Platinum(II) complexes such as carboplatin and oxaliplatin as well as other platinum ana$\operatorname{logs}$ are the products of this search. Other metal complexes containing ions such as zinc(II), gold and copper chelating agents have received considerable interest as anticancer agents. ${ }^{8,13}$ Recently, the chemistry of ruthenium and goldbased compounds has received intensive scrutiny, due to renewed interest in providing an alternative to cisplatin, because of their promising cytotoxic and potential anticancer properties. ${ }^{4,14,15}$
Nevertheless, metal-based compounds, especially transition metals, exhibit definite properties including their potential to undergo a redox reaction. ${ }^{5}$ Therefore, metals and their redox activities are tightly regulated to maintain normal wellbeing. ${ }^{5,16-21}$

Recently, there has been a growing demand for metalbased compounds in the treatment of cancer. This may be due to the scourge of cancer and, to the greater extent, the level of in vitro cytotoxic effect exhibited by metal-based compounds, particularly those synthesized recently. In addition, ligand substitution and modification of existing chemical structures led to the synthesis of a wide range of metal-based compounds, some of which have demonstrated an enhanced cytotoxic and pharmacokinetic profile. Again, a different approach of cytotoxic drug design has recently been adopted. This involves conjugating metallic compounds with bile acid, steroid, peptide or sugar to allow direct drug delivery to the cancer cells, thereby circumventing some pharmacokinetic challenges. The objective of this review is to provide an overview of previous reviews on the cytotoxic effects of metal-based compounds while focusing more on newly designed metal-based compounds and their cytotoxic effect on the cancer cell line, as well as on new approach to metal-based drug design in cancer therapy.

\section{Properties of metal complexes and metal-based compounds}

Transition metals are member elements of the "d" block and are included in groups III-XII of the periodic table. ${ }^{22}$ They possess unique properties that include:

- Charge variation: In aqueous solution, metal ions exist as positively charged species. Depending on the existing coordination environment, the charge can be modified to generate species that can be cationic, anionic or neutral. ${ }^{23}$ Most importantly, they form positively charged ions in aqueous solution that can bind to negatively charged biological molecules. ${ }^{8}$

- Structure and bonding: Relative to organic molecules, metal complexes can aggregate to a wide range of coordination geometries that give them unique shapes. The bond length, bond angle and coordination site vary depending on the metal and its oxidation state. ${ }^{23}$ In addition to this, metal-based complexes can be structurally modified to a variety of distinct molecular species that confer a wide spectrum of coordination numbers and geometries, as well as kinetic properties that cannot be realized by conventional carbon-based compounds. ${ }^{8,24,25}$ 
- Metal-ligand interaction: Different forms of metal-ligand interaction exist; however, these interactions usually lead to the formation of complexes that are unique from those of individual ligands or metals. The thermodynamic and kinetic properties of metal-ligand interactions influence ligand exchange reactions. ${ }^{23}$ The ability of metals to undergo this reaction offers a wide range of advantages to the metals to interact and coordinate with biological molecules. ${ }^{8}$

- Lewis acid properties: Characterized by high electron affinity, most metal ions can easily polarize groups that are coordinated to them, thus facilitating their hydrolysis. ${ }^{8,23}$

- Partially filled d shell: For transition metals, the variable number of electrons in the $d$ shell or $f$ shell (for lanthanides) influences the electronic and magnetic properties of transition metal complexes. ${ }^{23}$

- Redox activity: Many transition metals have a tendency to undergo oxidation and reduction reactions. ${ }^{23}$ The oxidation state of these metals is an important consideration in the design of the coordination compound. In biochemical redox catalysis, metal ions often serve to activate coordinated substrates and to participate in redox-active sites for charge accumulation.

Metal complexes and metal-based compounds possess the ability to coordinate ligands in a three-dimensional configuration, thereby allowing functionalization of groups that can be shaped to defined molecular targets. ${ }^{8}$

\section{Scope of metal complexes in the treatment of cancer}

Therapeutic potential of metal complexes in cancer therapy has attracted a lot of interest mainly because metals exhibit unique characteristics, such as redox activity, variable coordination modes and reactivity toward the organic substrate. ${ }^{8}$ These properties become an attractive probe in the design of metal complexes ${ }^{8}$ that selectively bind to the biomolecular target with a resultant alteration in the cellular mechanism of proliferation. Table 1 provides a summary of in vitro cytotoxic effect of various metal-based compounds within the period of 6 years with particular reference to their proposed mechanism of action and target.

Several metal-based compounds have been synthesized with promising anticancer properties, some of which are already in use in clinical practice for diagnosis and treatment while some are undergoing clinical trials. Metal-based compounds synthesized recently are products of drug design targeted at achieving specific objectives that the original compound could not achieve and such compounds exhibit a different spectrum of cytotoxicity. Compounds in this group include the following.

\section{Platinum complexes and associated ligands}

Platinum compounds, particularly cisplatin, are the heartbeat of the metal-based compounds in cancer therapy. Clinical use of platinum complexes as an adjuvant in cancer therapy is based on the desire to achieve tumor cell death ${ }^{26}$ and the spectrum of activity of the candidate drug. ${ }^{26}$ Such complexes are mostly indicated for the treatment of cervical, ovarian, testicular, head and neck, breast, bladder, stomach, prostate and lung cancers. Their anticancer activities are also extended to Hodgkin's and non-Hodgkin's lymphoma, neuroblastoma, sarcoma, melanoma and multiple myeloma. ${ }^{26}$ Although resistance to cisplatin emerged, it was the fundamental basis that triggered the search for alternative metallic compounds with improved anticancer and pharmacokinetic properties. On this basis, alternative platinum compounds were derived. Carboplatin, oxaliplatin, satraplatin, ormaplatin, aroplatin, enloplatin, zeniplatin, sebriplatin, miboplatin, picoplatin, satraplatin, and iproplatin are all products of extensive research of platinum complexes (Figure 1).

The US Food and Drug Administration (FDA) in 1978 approved Platinol ${ }^{\circledR}$, a brand of cisplatin, as a combination therapy in the management of metastatic testicular, ovarian and bladder cancers. ${ }^{27}$ FDA also approved Paraplatin ${ }^{\circledR}$ (carboplatin) as a combination therapy in the management of ovarian cancer. ${ }^{27}$ Numerous other platinum derivatives have been synthesized with established clinical success, including Eloxatin ${ }^{\circledR}$ (oxaliplatin), Aqupla ${ }^{\circledR}$ (nedaplatin) approved for use in Japan and lobaplatin approved for use in China.

Oxaliplatin was initially launched in France in 1996 and formally available in the countries of Europe in 1999 and the US in 2002. ${ }^{27}$ This is a platinum-based drug with oxalate and diaminocyclohexane ligand (DACH). The DACH plays a major role in cytotoxicity and protects it against cross-resistance with cisplatin and oxaliplatin. It is licensed to be used as a combination therapy with other chemotherapeutic agents in the management of colon cancer and non-small-cell lung cancer. ${ }^{28}$ This drug has better safety profile than cisplatin, as such is used in patients who cannot tolerate cisplatin. ${ }^{27}$ 
Table I An update on the anticancer activities of metal-based complexes (20I0-20I6)

\begin{tabular}{|c|c|c|c|c|}
\hline Metal complexes & Molecular formula & $\begin{array}{l}\text { Proposed mechanism } \\
\text { of action }\end{array}$ & $\begin{array}{l}\text { Target enzymes/cell lines/ } \\
\text { therapeutic indications }\end{array}$ & $I_{50}$ range $(\mu \mathrm{M})$ \\
\hline \multicolumn{5}{|c|}{ Carbene-metal complexes and related ligands } \\
\hline \multirow{8}{*}{$\begin{array}{l}\text { Novel gold(I) and } \\
\text { gold(III) NHC } \\
\text { complexes }^{62}\end{array}$} & \multirow{8}{*}{$\begin{array}{l}\mathrm{C}_{52} \mathrm{H}_{44} \mathrm{Au}_{2} \mathrm{~N}_{12} \mathrm{P}_{2} \mathrm{~F}_{12} \\
\mathrm{C}_{26} \mathrm{H}_{24} \mathrm{AuCl}_{2} \mathrm{OF}_{6} \mathrm{~N}_{6} \mathrm{P}\end{array}$} & Induction of apoptosis & $\operatorname{TrxR}$ & $\mathrm{C}_{52} \mathrm{H}_{44} \mathrm{Au}_{2} \mathrm{~N}_{12} \mathbf{P}_{2} \mathrm{~F}_{12}$ \\
\hline & & Inhibition of $\operatorname{Tr} \times \mathrm{R}^{62}$ & A549, HCTII6, HepG2, & $5.2 \pm 1.5(\mathrm{~A} 549)$ \\
\hline & & Induction of ROS ${ }^{62}$ & MCF7 & $3.6 \pm 4.1(\mathrm{HCT}-\mathrm{II})$ \\
\hline & & & Chemotherapy of solid & $3.7 \pm 2.3(\mathrm{HepG} 2)$ \\
\hline & & & tumors ${ }^{62}$ & $\begin{array}{l}4.7 \pm 0.8(\mathrm{MCF} 7)^{62} \\
\mathbf{C}_{26} \mathrm{H}_{24} \mathrm{AuCl}_{2} \mathrm{OF}_{6} \mathrm{~N}_{6} \mathrm{P} \\
5.2 \pm 3.0(\mathrm{~A} 549)\end{array}$ \\
\hline & & & & $5.9 \pm 3.6(\mathrm{HCT}-\mathrm{II} 6)$ \\
\hline & & & & $5.1 \pm 3.8(\mathrm{HepG} 2)$ \\
\hline & & & & $6.2 \pm 1.4(\text { MCF7) })^{62}$ \\
\hline Caffeine-based & {$\left[\mathrm{Au}(\text { Caffeine-2-yielding })_{2}\right]$} & Inhibition of protein & DNA & $0.54-28.4(\mathrm{~A} 2780)$ \\
\hline \multirow[t]{4}{*}{$\operatorname{gold}(\mathrm{I}) \mathrm{NHCs}^{81}$} & \multirow{4}{*}[\mathrm{BF}_{4}]{$^{81}$} & \multirow[t]{4}{*}{ PARP- $\left.\right|^{81}$} & A2780, A2780R, SKOV3, & I7.I-49 (A2780/R) \\
\hline & & & A549 and HEK-293T & $0.75-62.7$ (SKOV3) \\
\hline & & & & $5.9-90.0$ (A549) \\
\hline & & & & 0.20-84 (HEK-293T) \\
\hline Ester- and amide- & $\left\{\left[\mathrm{Im}^{\mathrm{A}}\right] \mathrm{AgCl}\right\}$ & Inhibition of tyrosine & $\operatorname{Tr} \times R^{82}$ & $\left\{\left[\mathrm{Im}^{\mathrm{A}}\right] \mathrm{AgCl}\right\}$ \\
\hline functionalized & $\left\{\left[\mathrm{Im}^{\mathrm{A}}\right] \mathrm{AuCl}\right\}$ & by gold(I) NHC ligands, & $\mathrm{A} 375, \mathrm{~A} 549, \mathrm{HCT}-15$ and & $24.65(\mathrm{~A} 375)$ \\
\hline imidazole of $\mathrm{NHC}$ & $\left\{\left[\mathrm{Im}^{\mathrm{B}}\right]_{2} \mathrm{AgCl}\right\}$ & thereby targeting $\operatorname{Tr} \times \mathrm{R}^{82}$ & MCF7 & 22.14 (A549) \\
\hline \multirow[t]{12}{*}{ complexes $^{82}$} & $\left\{\left[\mathrm{Im}^{\mathrm{B}}\right] \mathrm{AuCl}\right\}$ & $\mathrm{CuNHC}$ cell cycle arrest & Human colon & $20.32($ HCT-I5) \\
\hline & $\mathrm{HIm}^{A} \mathrm{Cl}=[1,3$-bis & progression in $\mathrm{Gl}$ phase $\mathrm{e}^{82}$ & adenocarcinoma, ${ }^{82}$ leukemia & 21.14 (MCF7) \\
\hline & (2-ethoxy-2-oxoethyl)-IH- & Anticancer activity of & and breast cancer ${ }^{82}$ & $\left\{\left[\mathrm{Im}^{\mathrm{A}}\right] \mathrm{AuCl}\right\}$ \\
\hline & imidazol-3-ium chloride] & $\mathrm{Ag}^{\prime} \mathrm{NHC}$ is based on & & $44.64(\mathrm{~A} 375)$ \\
\hline & $\mathrm{HIm}^{\mathrm{B}} \mathrm{Cl}=\{\mathrm{I}, 3-$ & highly lipophilic aromatic- & & 42.37 (A549) \\
\hline & bis[2(diethylamino)-2- & substituted carbenes $^{82}$ & & 41.33 (HCT-I5) \\
\hline & oxoethyl]-IH-imidazol-3-ium & & & 38.53 (MCF7) \\
\hline & \multirow[t]{5}{*}{ chloride\} } & & & $\left\{\left[\mathrm{Im}^{\mathrm{B}}\right]_{2} \mathrm{AgCl}\right\}$ \\
\hline & & & & $24.46(\mathrm{~A} 375)$ \\
\hline & & & & $16.23($ A549) \\
\hline & & & & $14.11(\mathrm{HCT}-15)$ \\
\hline & & & & I5.3। (MCF7) $)^{82}$ \\
\hline \multirow[t]{3}{*}{ Novel Ru(II) NHCs ${ }^{83}$} & \multirow{3}{*}{$\begin{array}{l}{\left[\left(\eta^{6} \text {-p-cymene }\right)_{2} \mathrm{Ru}_{2}\left(\mathrm{Cl}_{2}\right)_{2}\right]} \\
\mathrm{NHC}\end{array}$} & Mimic iron ${ }^{84}$ & DNA as target & I3-500 (Caki-I) \\
\hline & & Interact with plasmidic & Caki-I and MCF7 & $2.4-500$ (MCF7) ${ }^{83}$ \\
\hline & & DNA $^{84}$ & $\begin{array}{l}\text { Chemotherapy of solid } \\
\text { tumor }^{66}\end{array}$ & \\
\hline Caffeine-derived & {$[\mathrm{Rh}(\mathrm{I}) \mathrm{Cl}(\mathrm{COD})(\mathrm{NHC})]$} & Inhibition of $\operatorname{TrxR}^{85}$ & $\operatorname{Tr} \times R^{85}$ & 84 (HepG2) \\
\hline rhodium(I) NHC & \multirow[t]{6}{*}{ complexes } & Increase in ROS & MCF7, HepG2 MDA-MB-23I, & 20 (HCF-7) \\
\hline \multirow{5}{*}{ complexes $^{85}$} & & formation ${ }^{85}$ & HCT-II6, LNCaP, Panc-I & 23 (MDA-MB-23I) \\
\hline & & DNA damage ${ }^{85}$ & and JoPaca-I & 35 (JoPaca-I) \\
\hline & & Cell cycle arrest ${ }^{85}$ & Chemotherapy of solid & 49 (Panc-I) \\
\hline & & Decrease in mitochondria & tumor ${ }^{85}$ & 80 (LNCaP) \\
\hline & & membrane potential ${ }^{85}$ & & $9.0(\mathrm{HCT}-\mathrm{I} 16)^{85}$ \\
\hline NHC-amine Pt(II) & $\mathrm{NHC}(\mathrm{Pt} \times 2)-$ amine & Nuclear DNA & Target DNA ${ }^{86}$ & $2.5($ KB3-I) \\
\hline \multirow[t]{5}{*}{ complexes $^{86}$} & \multirow[t]{5}{*}{ complexes $^{86}$} & \multirow[t]{5}{*}{ platination $^{86}$} & KB3-I, SK-OV3, OVCAR-8, & 4.33 (SK-OV3) \\
\hline & & & MV-4-II, A2780 and A2780/ & 1.84 (OVCAR-8) \\
\hline & & & DPP & $0.60(\mathrm{MV}-4-\mathrm{II})$ \\
\hline & & & Chemotherapy of solid and & $4.00(\mathrm{~A} 2780)$ \\
\hline & & & non-solid tumors ${ }^{86}$ & $8.5(\mathrm{~A} 2780 / \mathrm{DPP})^{86}$ \\
\hline \multirow{5}{*}{$\begin{array}{l}\text { 2-Hydroxy-3- } \\
\text { [(hydroxyimino)-4- } \\
\text { oxopentan-2-ylidene] } \\
\text { benzohydrazide } \\
\text { derivatives }^{87}\end{array}$} & \multirow{5}{*}{$\begin{array}{l}{\left[(\mathrm{HL}) \mathrm{Cu}(\mathrm{OAc})\left(\mathrm{H}_{2} \mathrm{O}\right)_{2}\right] \cdot \mathrm{H}_{2} \mathrm{O}} \\
\mathrm{Cl}_{4} \mathrm{H}_{21} \mathrm{~N}_{3} \mathrm{O}_{9} \mathrm{Cu}\end{array}$} & \multirow[t]{5}{*}{ Bind to $\mathrm{DNA}^{87}$} & Target DNA ${ }^{87}$ & $2.24-6.49(\mathrm{HepG} 2)^{87}$ \\
\hline & & & HepG2 & \\
\hline & & & Chemotherapy of solid & \\
\hline & & & tumors ${ }^{87}$ & \\
\hline & & & & \\
\hline Molybdenum(II) & \multirow{3}{*}{$\mathrm{Mo}(\mathrm{allyl})(\mathrm{CO})_{2}(\mathrm{~N}-\mathrm{N})(\mathrm{Py}) \mathrm{PF}_{6}$} & DNA fragmentation ${ }^{88}$ & Target DNA ${ }^{88}$ & I.8-I3 (NALM-6) \\
\hline allyl dicarbonate & & Induction of apoptosis ${ }^{88}$ & NALM-6, MCF7 and HT-29 & $2.1-32$ (MCF7) \\
\hline complexes $^{88}$ & & & $\begin{array}{l}\text { Chemotherapy of solid and } \\
\text { non-solid tumors }\end{array}$ & I.8-32 (HT-29) $)^{88}$ \\
\hline
\end{tabular}


Table I (Continued)

\begin{tabular}{|c|c|c|c|c|}
\hline Metal complexes & Molecular formula & $\begin{array}{l}\text { Proposed mechanism } \\
\text { of action }\end{array}$ & $\begin{array}{l}\text { Target enzymes/cell lines/ } \\
\text { therapeutic indications }\end{array}$ & $I_{50}$ range $(\mu M)$ \\
\hline \multicolumn{5}{|c|}{ Metal-arene complexes and other ligands } \\
\hline $\begin{array}{l}\text { Ru(II)-arene } \\
\text { complex }\end{array}$ & {$\left[\left(\eta^{6} \text {-arene }\right) \mathrm{Ru}(\mathrm{II})(\mathrm{en}) \mathrm{Cl}\right]^{+}$} & $\begin{array}{l}\text { DNA damage } \\
\text { Cell cycle arrest } \\
\text { Induction of apoptosis }^{89}\end{array}$ & $\begin{array}{l}\text { Target DNA } \\
\text { AH54 and AH63 } \\
\text { Chemotherapy of colorectal } \\
\text { cancer }^{89}\end{array}$ & $\begin{array}{l}\mathbf{C}_{15} \mathbf{H}_{18} \mathbf{C}_{1} \mathbf{F}_{6} \mathbf{N}_{2} \mathbf{P R u} \\
16.6(\mathrm{AH} 54)^{89} \\
\mathbf{C}_{16} \mathbf{H}_{2} \mathbf{O C} \mathbf{C}_{1} \mathbf{F}_{6} \mathbf{N}_{2} \mathbf{P R u} \\
10.9(\mathrm{AH} 63)^{89}\end{array}$ \\
\hline $\begin{array}{l}\text { Novel ruthenium- } \\
\text { arene pyridinyl } \\
\text { methylene } \\
\text { complexes }^{90}\end{array}$ & $\begin{array}{l}{\left[\left(\eta^{6}-\mathrm{p}-\text { cymene }\right) \mathrm{RuCl}\right.} \\
\text { (pyridinylmethylene) }]\end{array}$ & DNA binding ${ }^{90}$ & $\begin{array}{l}\text { Target DNA } \\
\text { MCF7 and HeLa } \\
\text { Chemotherapy of solid } \\
\text { tumor }^{90}\end{array}$ & $\begin{array}{l}07.76-25.42(\mathrm{MCF}) \\
07.10-29.22(\mathrm{HeLa})^{90}\end{array}$ \\
\hline $\begin{array}{l}\text { Multi-targeted } \\
\text { organometallic } \\
\text { Ru(II)-arene }\end{array}$ & $\begin{array}{l}{\left[\left(\eta^{6}-\mathrm{p}-\mathrm{cymene}\right) \mathrm{RuCl}_{2}\right] 2-\mathrm{PARP}} \\
\text { and PARP-I inhibitors }\end{array}$ & $\begin{array}{l}\text { DNA binding' } \\
\text { PARP-I inhibition } \\
\text { Transcription inhibition }\end{array}$ & $\begin{array}{l}\text { Target DNA } \\
\text { A549, A2780, HCT-I I6, } \\
\text { HCCI937 and MRC-5 } \\
\text { Chemotherapy of solid } \\
\text { tumors }\end{array}$ & $\begin{array}{l}85.1-500 \text { (A549) } \\
38.8-500(\text { A2780) } \\
46.0-500(\mathrm{HCT}-116) \\
93.3-500(\mathrm{HCCl} 937) \\
\text { I43-500(MRC-5) })^{91}\end{array}$ \\
\hline $\begin{array}{l}\mathrm{Ru}(\mathrm{II}) \text {-arene } \\
\text { complexes with } \\
\text { 2-aryldiazole ligands }{ }^{92}\end{array}$ & {$\left[\left(\eta^{6}\right.\right.$-arene $\left.) \mathrm{RuX}\left(\mathrm{k}^{2}-\mathrm{N}, \mathrm{N}-\mathrm{L}\right)\right] \mathrm{Y}$} & $\begin{array}{l}\text { DNA binding } \\
\text { Inhibition of CDKI }\end{array}$ & $\begin{array}{l}\text { Target DNA }{ }^{92} \\
\text { A2780, A2780cis, MCF7 and } \\
\text { MRC-5 } \\
\text { Chemotherapy of solid } \\
\text { tumors }\end{array}$ & $\begin{array}{l}\text { II-300 (A2780) } \\
\text { II-34 (A2780cis) } \\
26-300 \text { (MCF7) } \\
25-224 \text { (MRC-5) }\end{array}$ \\
\hline $\begin{array}{l}\text { Osmiun(II)-arene } \\
\text { carbohydrate } \\
\text { base anticancer } \\
\text { compound }{ }^{93}\end{array}$ & $\begin{array}{l}\text { Osmium(II)-bis [dichloride }\left(\eta^{6}-\right. \\
\text { p-cymene)] }\end{array}$ & DNA binding ${ }^{93}$ & $\begin{array}{l}\text { Target DNA }{ }^{93} \\
\mathrm{CHI}, \mathrm{SW} 480 \text { and A549 }\end{array}$ & $\begin{array}{l}50-746(\mathrm{CHI}) \\
2 \mathrm{I} 5-640(\mathrm{SW} 480) \\
640(\mathrm{~A} 549)^{93}\end{array}$ \\
\hline $\begin{array}{l}\mathrm{Ru}(\mathrm{II}) \text {-arene } \\
\text { complexes with } \\
\text { carbosilane } \\
\text { metallodendrimers }^{94}\end{array}$ & $\begin{array}{l}\mathrm{G}_{\mathrm{n}}-\left[\mathrm{NH}_{2} \mathrm{Ru}\left(\eta^{6} \text {-p-cymene }\right)\right. \\
\left.\mathrm{Cl}_{2}\right] \mathrm{m}\end{array}$ & $\begin{array}{l}\text { Interaction with DNA }{ }^{94} \\
\text { Interaction with } \mathrm{HSA}^{94} \\
\text { Inhibition of cathepsin } \mathrm{B}^{94}\end{array}$ & $\begin{array}{l}\text { Target DNA } \\
\text { HeLa, MCF, HT-29 MDA- } \\
\text { MB-23I and HEK-239T } \\
\text { Chemotherapy of solid and } \\
\text { non-solid tumors }\end{array}$ & $\begin{array}{l}\text { 6.3-89 (HeLa) } \\
\text { 2.5-56.0 (MCF7) } \\
\text { 3.3-4I.7 (HT-29) } \\
\text { 4-74 (MDA-MB-23I) } \\
\text { 5.0-51.9 (HEK-239T) }\end{array}$ \\
\hline $\begin{array}{l}\mathrm{Ru}(\mathrm{II}) \text { complexes } \\
\text { with aroylhydrazone } \\
\text { ligand }\end{array}$ & {$\left[\mathrm{Ru}\left(\eta^{6}-\mathrm{C}_{6} \mathrm{H}_{6}\right) \mathrm{Cl}(\mathrm{L})\right]$} & $\begin{array}{l}\text { Induction of apoptosis } \\
\text { Fragmentation of } \mathrm{DNA}^{95}\end{array}$ & $\begin{array}{l}\text { Target DNA } \\
\text { MCF7, HeLa, NIH-3T3 } \\
\text { Chemotherapy of solid } \\
\text { tumor }\end{array}$ & $\begin{array}{l}\text { I0.9-15.8 (MCF7) })^{95} \\
34.3-48.7(\mathrm{HeLa}) \\
\text { I52.6-192(NIH-3T3) }\end{array}$ \\
\hline \multicolumn{5}{|c|}{ Cyclopentadienyl complexes and other ligands } \\
\hline $\begin{array}{l}\text { Iridium(III) complexes } \\
\text { with 2-phenylpyridine } \\
\text { ligand }{ }^{96}\end{array}$ & $\begin{array}{l}{\left[\left(\eta^{5}-C_{p}^{*}\right) \operatorname{Ir}\left(2-\left(R^{\prime}-p h e n y l\right)-R-\right.\right.} \\
\text { pyridine }) C l]\end{array}$ & $\begin{array}{l}\text { Interaction with DNA } \\
\text { nucleobases }{ }^{96} \\
\text { Catalysis of NADH } \\
\text { oxidation }^{96}\end{array}$ & $\begin{array}{l}\text { Target DNA } \\
\text { A6 } 2780, \text { HCT-I I6, MCF7 and } \\
\text { A549 } \\
\text { Chemotherapy of solid } \\
\text { tumor }^{96}\end{array}$ & $\begin{array}{l}\text { 1.18-60 (A2780) } \\
3.7-57.3 \text { (HCT-I I6) } \\
4.8-28.6 \text { (MCF7) } \\
2.1-56.67\left(\text { A549) }{ }^{96}\right.\end{array}$ \\
\hline $\begin{array}{l}\text { New iron(II) } \\
\text { cyclopentadienyl } \\
\text { derivative } \\
\text { complexes }^{97}\end{array}$ & {$\left[\mathrm{Fe}\left(\eta^{5}-\mathrm{C}_{5} \mathrm{H}_{5}\right)(\mathrm{dppe}) \mathrm{L}\right][\mathrm{X}]$} & $\begin{array}{l}\text { Interaction with DNA } \\
\text { Induction of apoptosis }\end{array}$ & $\begin{array}{l}\text { Target DNA } \\
\text { HL- } 60 \\
\text { Chemotherapy of non-solid } \\
\text { tumors }^{97}\end{array}$ & $0.67-5.89(\mathrm{HL}-60)$ \\
\hline $\begin{array}{l}\text { Ru(II) } \\
\text { cyclopentadienyl } \\
\text { complexes with } \\
\text { carbohydrate } \\
\text { ligand }\end{array}$ & {$\left[\mathrm{Ru}\left(\eta^{5}-\mathrm{C}_{5} \mathrm{H}_{5}\right)(\mathrm{PP})(\mathrm{L})\right][\mathrm{X}]$} & $\begin{array}{l}\text { Induction of apoptosis } \\
\text { Activation of caspase- } 3 \\
\text { and }-7 \text { activity }\end{array}$ & $\begin{array}{l}\text { HCTII6CC, HeLa } \\
\text { Chemotherapy of solid } \\
\text { tumors }^{98}\end{array}$ & $\begin{array}{l}0.45(\mathrm{HCTI} \text { I6CC) } \\
3.58(\mathrm{HeLa})^{98}\end{array}$ \\
\hline $\begin{array}{l}\text { Ru(II) } \\
\text { cyclopentadienyl } \\
\text { complexes with } \\
\text { phosphane } \\
\text { co-ligand }^{98}\end{array}$ & {$\left[\mathrm{Ru}\left(\eta^{5}-\mathrm{C}_{5} \mathrm{H}_{5}\right)(\mathrm{PP})(\mathrm{L})\right][\mathrm{X}]$} & Induction of apoptosis ${ }^{98}$ & $\begin{array}{l}\text { HeLa } \\
\text { Chemotherapy of solid } \\
\text { tumor }^{98}\end{array}$ & $2.63(\mathrm{HeLa})^{98}$ \\
\hline $\begin{array}{l}\text { Organoiridium } \\
\text { cyclopentadienyl } \\
\text { complexes }^{99}\end{array}$ & {$\left[\left(\eta^{5}-C_{p x}\right) \operatorname{Ir}\left(L^{\wedge} L^{\prime}\right) Z\right]$} & $\begin{array}{l}\text { Intercalation of DNA } 99 \\
\text { Coordination with DNA } \\
\text { guanine }^{99}\end{array}$ & $\begin{array}{l}\text { HeLa } \\
\text { Chemotherapy of solid } \\
\text { tumor }^{99}\end{array}$ & $0.23(\mathrm{HeLa})^{99}$ \\
\hline
\end{tabular}

Abbreviations: $\mathrm{IC}_{50}$, half maximal inhibitory concentration; NHC, N-heterocyclic carbene; TrxR, thioredoxin reductase; ROS, reactive oxygen species; PARP-I, Poly(ADP-ribose) polymerase-I; CDKI, cyclin-dependent kinase I; HSA, human serum albumin; ADP, adenosine diphosphate. 


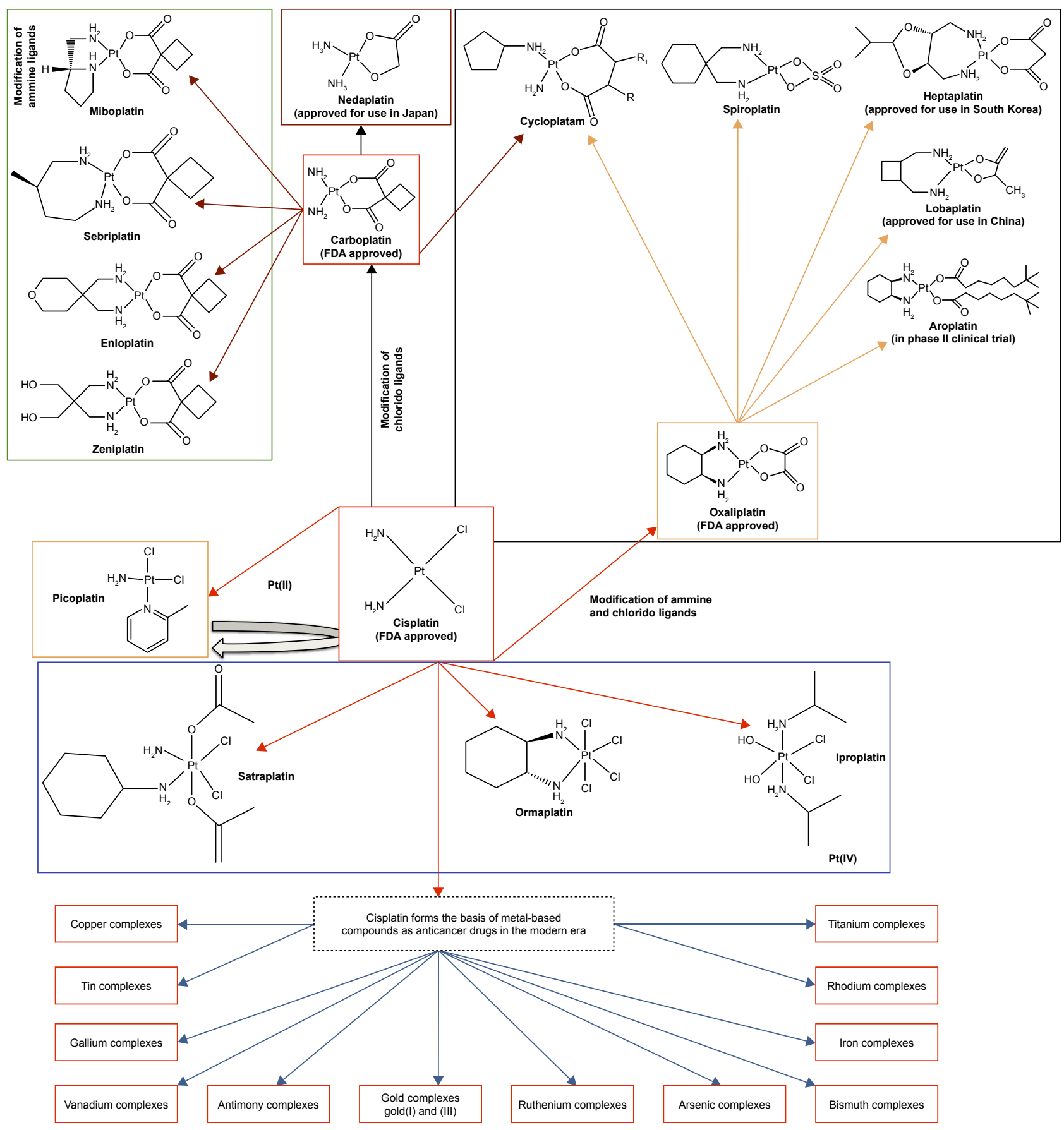

Figure I Evolution of organometallic complexes in cancer therapy.

Abbreviation: FDA, US Food and Drug Administration.

Nedaplatin is a platinum derivative of cis-diamine (glycolate), which was formally approved in Japan in 1995. The drug is said to have a better safety profile than cisplatin (less nephrotoxic) ${ }^{29}$ and is used as a combination therapy in the management of urological tumors. ${ }^{29}$

Lobaplatin is a derivative of the platinum compound, represented as 1,2-diammino-1-methyl-cyclobutaneplatinum(II)-lactate. The antitumor activities of this compound span through the human lung, ovarian and gastric cancer xenografts. ${ }^{27}$ It has non-cross-resistance to cisplatin, particularly human sensitive cancer cells. Lobaplatin was originally approved for use in the management of patients with chronic myelogenous leukemia, small-cell lung cancer (SCLC) and metastatic cancer. ${ }^{30}$ Recently, a phase I clinical trial of dose escalation of lobaplatin in combination with fixed-dose docetaxel in the treatment of human solid tumor was established. ${ }^{31}$ In this study, the maximum tolerable dose of lobaplatin when combined with docetaxel for the 
treatment of solid tumor, known to have progressed after chemotherapy, was established..$^{31}$ Positive results from the phase I trial prompted researcher to recommend the same dosage for the phase II clinical trial. ${ }^{31}$

Picoplatin is a 2-methylpyridine analog of cisplatin (formerly known as ZD0473) originally developed to provide steric cover around the platinum center, thereby providing a steric hindrance to the drug and preventing the attack from nucleophiles. It shields it against DNA-repair pathway that enhanced resistance. ${ }^{32}$ Preclinical studies ${ }^{33}$ revealed promising anticancer activities in the resistant cell line to cisplatin. ${ }^{28}$ However, after the phase II clinical trial was conducted, it was noted that picoplatin offers no superior advantage on the targeted cell line except a significant decrease in neurotoxicities. ${ }^{28}$ In a related development, picoplatin is still undergoing phase I and II clinical trials as a treatment for colorectal cancer in combination with 5-fluorouracil (FU) and leucovorin and also in combination with docetaxel for prostate cancer. ${ }^{34}$

Satraplatin, bis-(acetate)-ammine dichloro(cyclohexylamine) platinum (IV), is the first orally bioavailable platinum drug. This drug exhibits varying pharmacodynamics and pharmacokinetic properties relative to other platinum compounds and hence may possess a different spectrum of anticancer activities. ${ }^{27}$ The anticancer activities of satraplatin span through platinum-sensitive and resistant cell lines, including cervical, prostate, ovarian and lung cancers. ${ }^{34}$ Nonlinear pharmacokinetics was one major challenge encountered during the initial studies of satraplatin that led to the study being abandoned. ${ }^{34}$ Satraplatin has undergone several phases of clinical trials. Phase III clinical trials examined satraplatin and prednisolone combination against refractory cancer. ${ }^{34}$ Satraplatin is currently targeted in phase I, II and III trials in combination with other drugs such as docetaxel in the treatment of prostate cancer.

Lipoplatin is a liposomal form of cisplatin designed to enhance the pharmacokinetic safety profile and allow dosage manipulation while targeting cancer cells. ${ }^{34}$ The liposomes are made of dipalmitoyl phosphotidylglycerol, soyphosphatidyl choline, cholesterol and methoxy-polyethylene glycol-distreatoyl phosphatidyl-ethanolamine. ${ }^{34}$ The presence of liposomes offered a circulatory advantage to the drug. Lipoplatin has undergone phase I, II and III clinical trials with the main focus on its anticancer activity in SCLC. ${ }^{34}$ It is also being investigated for breast, pancreatic, head and neck anticancers.

ProLindac ${ }^{\mathrm{TM}}$ is an oxaliplatin with hydrophilic (hydroxypropylmethacrylamide) polymer bonded to the active moiety. This drug is designed to target the solid tumor with enhanced retention within the tumor cells. ${ }^{35}$ Anticancer activities of ProLindac have been evaluated in mice with ovarian carcinoma and B16 melanoma. ${ }^{34}$ In this study, an optimum growth inhibitory effect was achieved in addition to a decrease in toxicity toward a normal cell and sustained plasma concentration. This drug has undergone both phase I and phase II clinical trials with profound anticancer activities. It is used as a monotherapy in advanced ovarian cancer resistant to platinum therapy. ${ }^{36}$ The drug is currently undergoing phase III clinical trials in the treatment of head and neck cancer. ${ }^{36}$

\section{Platinum drugs discontinued}

In the midst of several challenges on the use of platinum drugs in the management of a spectrum of cancers, many platinum compounds have been synthesized and demonstrate good in vitro cytotoxic activity. However, the use of these compounds in the treatment of cancer would depend on scientific evidence from clinical trials (Table 2), such result should provide details of pharmacokinetics, pharmacodynamics and safety profile of the drug in humans, in addition, Patient Social-economic factors are also considered. In this case, studies of platinum compounds are discontinued due to either toxicity or lack of profound anticancer activity on the patient. Many platinum-based drugs have been screened through clinical trials in an attempt to find an alternative to cisplatin, mainly due to dose-related adverse effects or resistance to cisplatin. The lack of superior advantage of these drugs over cisplatin led to the suspension from the study. Platinum drugs discontinued from clinical trials include sebriplatin, spiroplatin, cycloplatam, miboplatin, SPI-077, aroplatin, BBR3464, TRK-710, iproplatin, zeniplatin, enloplatin, ormaplatin JM 11 and NSC 170898.

\section{New platinum complexes as a product of drug design}

Recently, more platinum complexes are being synthesized, and their anticancer activities against tumor cell lines are being evaluated. This involves remodeling of the parent compound (platinum) by conjugating it with the different ligand to achieve the desired outcome. In most cases, pharmacokinetic parameters, spectrum of activity and toxicity profile are improved to circumvent those challenges inherent from the parent compound. This includes the following.

\section{Platinum complexes conjugated with sugar}

Carbohydrate (sugar) conjugation may bring about biological and physicochemical changes to the platinum compound. ${ }^{37}$ The changes may be in the form of improved solubility, 
Table 2 Summary of metal-based compounds undergoing clinical trials in human

\begin{tabular}{|c|c|c|c|}
\hline Drug name & Developers & Phase of clinical trial & Indications \\
\hline Picoplatin ${ }^{68}$ (JM473) & Pionard & Phase II & $\begin{array}{l}\text { Treatment of colorectal cancer }{ }^{68} \text { in combination } \\
\text { with } 5-\mathrm{FU} \text { and leucovorin }\end{array}$ \\
\hline $\begin{array}{l}\text { Lipoplatin }^{\mathrm{TM}} \\
\text { (Nanoplatin }^{\mathrm{TM}} \text {, Oncoplatin) }\end{array}$ & Regulon & $\begin{array}{l}\text { Phase } 1{ }^{168} \text { and phase III clinical } \\
\text { trial in different cancer cells }\end{array}$ & $\begin{array}{l}\text { Treatment of locally advanced gastric cancer/ } \\
\text { squamous cell carcinoma of head and neck }\end{array}$ \\
\hline ProLindac ${ }^{\mathrm{TM}}$ (AP5046) & Access Pharm & Phase I, II and III trials & Advanced ovarian cancer ${ }^{68}$ and head and neck cancers \\
\hline Satraplatin (JM2I6) & $\begin{array}{l}\text { Spectrum Pharm } \\
\text { and Agennix AG }\end{array}$ & Phase I, II and III trials & $\begin{array}{l}\text { Treatment of colorectal cancer in combination with } \\
5 \text {-FU and leucovorin, }{ }^{68} \text { treatment of prostate cancer } \\
\text { in combination with docetaxel and treatment of } \\
\text { a patient with progressive or relapse NSCLC }{ }^{68}\end{array}$ \\
\hline NAMIA-A & - & Phase I & $\begin{array}{l}\text { Metastatic tumor (lung, colorecta, melanoma, ovarian } \\
\text { and pancreatic) } \text { ) }^{100}\end{array}$ \\
\hline KPIOI9 & - & Phase II & Advanced colorecta cancer ${ }^{100}$ \\
\hline${ }^{64} \mathrm{Cu}-\mathrm{ATSM}$ & - & Phase II & $\begin{array}{l}\mathrm{PET} / \mathrm{CT} \text { monitoring therapeutic progress in patient } \\
\text { with cervica }{ }^{101}\end{array}$ \\
\hline
\end{tabular}

Abbreviations: FU, fluorouracil; NSCLC, non-small-cell lung cancer; ${ }^{64} \mathrm{Cu}-\mathrm{ATSM},{ }^{64} \mathrm{Cu}$-diacetyl-bis(N${ }^{4}$-methylthiosemicarbazone); PET, positron emission tomography; $\mathrm{CT}$, computed tomography.

a decrease in adverse effects and improvement in cellular uptake of the drug. ${ }^{37}$ Most of the newly synthesized platinum compounds have been evaluated for their anticancer activities. Recently, compounds such as [PtIICl ${ }_{2}$ (AcGlc-pyta)] have been synthesized and their cytotoxicity profiles have been evaluated in vitro against human cervical tumor (HeLa) and compared with the effect of cisplatin. The compound showed less cytotoxicity. ${ }^{37}$ Figure 2 is a typical example of sugar-conjugated triazole ligand.

In order to deliver the platinum drugs directly into the cells, 2-deoxyglucose (2-DG) conjugated platinum(II) (conjugated platinum(II) complex for glucose transporter-1) also known as GLUTI1 was designed to transport the drug to the cancer cells. ${ }^{38}$ This was possibly due to the fact that to maintain cellular homeostasis, growth and proliferation, malignant cells exhibit a higher rate of glycolysis than the normal cells. ${ }^{38,39}$ GLUTI1 was evaluated for its potential to transport the drug complex with the aid of comparative molecular docking analysis using the latest GLUTI crystal structure. Molecular dynamics (MD) was used in identifying the key binding site of 2-DG as a substrate for GLUTI. ${ }^{38}$ The findings from the docking result revealed that the 2-DG conjugated platinum complex can bind to the same binding site as the GLUTI substrate. ${ }^{38}$ This led to the synthesis

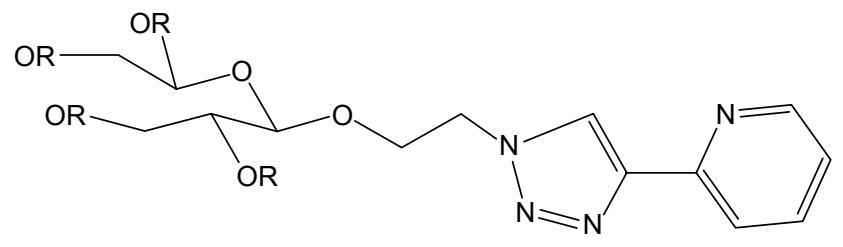

Figure 2 Sugar-conjugated triazole ligands.

Notes: AcGlc-pyta (conjugate a) $\mathrm{R}=$ Ac. Glc-pyta (conjugate b) $\mathrm{R}=\mathrm{H}$. of the conjugate (a) and (b) and were evaluated for their cytotoxicity. This study provides critical information about the potential of 2-DG conjugated platinum(II) compound in pharmaceutical research and drug development. ${ }^{38}$

In a related development, a recent study on potent glucose platinum conjugate ${ }^{39}$ revealed the potential of novel Glc-pts in cancer therapy. The crystal structure of recently published bacterial xylose transporter XyIE was used for the docking, ${ }^{39}$ and C6-glucose-platinum derivative was initially optimized using DFT before docking it to the protein. A good hydrogen bond interaction with key glucose binding residues Gln168, Gln288, Tyr298 and Gln $175^{39}$ was revealed. The cytotoxicity studies conducted against ovarian cancer cell line (A2780) show that A2780 cells were the most sensitive to Glc-pts compounds with half maximal inhibitory concentration $\left(\mathrm{IC}_{50}\right)$ values of $0.15-0.22 \mu \mathrm{M}$.

\section{Chiral platinum complexes}

The biological activities of the chiral compound have attracted a great deal of research. These compounds display a high level of selectivity and specificity and are involved in many biological events. ${ }^{40}$ To overcome many challenges with cisplatin and other platinum drugs already in clinical use, numerous drug design approaches have been adopted. One such approach is metal-drug synergism, ${ }^{40}$ which can be achieved by combining a known active organic compound with a metal-based complex. ${ }^{40}$ The structure of DNA and other biomolecules can be probed with chiral metallic complexes; ${ }^{40}$ therefore, biological activities are greatly influenced by the nature of chiral molecules present in the system. ${ }^{40}$ In a recent study of chiral platinum complexes, the DNA binding characteristic of platinum was combined with the chemical properties of phosphine and chloroquine. ${ }^{40}$ 
The cytotoxicity profile of these compounds against cancer cell lines $\left(\mathrm{IC}_{50}\right)$ is as follows: MDA-MB-231 $(200 \mu \mathrm{M}$ for chloroquine and $2.44 \mu \mathrm{M}$ for cisplatin-phosphine complex), MCF7 (82.0 $\mu \mathrm{M}$ for clioquinol [CQ] and $13.98 \mu \mathrm{M}$ for cisplatin-phosphine complex), A459 $(56.53 \mu \mathrm{M}$ for CQ and $14.42 \mu \mathrm{M}$ for CDDP), DU-145 (79.50 $\mu \mathrm{M}$ for CQ and $2.33 \mu \mathrm{M}$ for CDDP), V79-4 (29.85 $\mu \mathrm{M}$ for CQ and $21.60 \mu \mathrm{M}$ for CDDP) and L929 (25.94 $\mu \mathrm{M}$ for CQ and $16.53 \mu \mathrm{M}$ for CDDP). In correlation with the biological activities of phosphine chloroquine platinum(II) complexes, it was revealed that the compounds display a lower biological activity even at relatively higher DNA interaction and higher affinity for blood plasma protein. ${ }^{40}$ Owing to high protein affinity exhibited by this compound, the effect on DNA is greatly reduced, and consequently, the cytotoxic effect is also affected. A desired effort is needed to devise means of displacing or reducing plasma binding of these compounds to enhance their interaction with DNA.

\section{Monofunctional platinum(II) complexes}

Some platinum complexes have the ability to bind to DNA only through one coordination site, particularly chloride ligand. ${ }^{41}$ Many of these compounds have been synthesized with only a few exhibiting in vitro cytotoxic effects against a range of cancer cell lines. ${ }^{41}$ Phenanthriplatin, a monofunctional platinum complex (Figure 3), exhibited a relatively better cytotoxic effect than cisplatin. It was thought that the biological activity of these complexes arises from monofunctional adduct. This is a sequel to the failure of antibodies of DNA containing bifunctional platinum adduct to recognize the lesion formed by $c i s-\left[\mathrm{Pt}\left(\mathrm{NH}_{3}\right)_{2}(\mathrm{Am}) \mathrm{Cl}\right]+$.

This means that the complexes bind to DNA with a favorable biological effect through a monofunctional adduct formation. ${ }^{41}$

\section{Platinum(IV) complexes and anticancer activity}

Since the discovery of cisplatin and its clinical use, there has been an effort for the search of improved platinum drugs

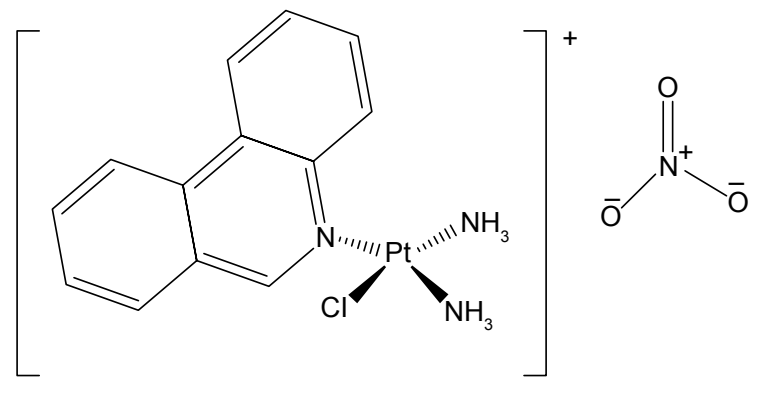

Figure 3 Structure of phenanthriplatin.

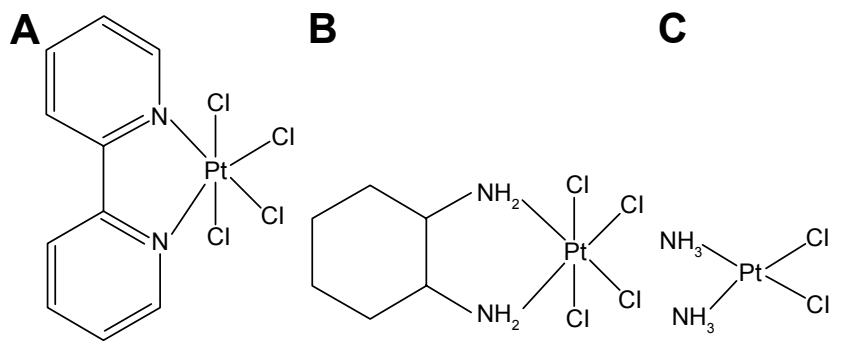

Figure 4 Structure of platinum(IV) complexes under investigation: (A) $\left[\mathrm{PtCl}_{4}(\right.$ bipy) $]$, (B) $\left[\mathrm{PtCl}_{4}(\mathrm{dach})\right]$ and $(\mathbf{C})$ cis-[ $\left[\mathrm{PtCl}_{2}\left(\mathrm{NH}_{3}\right)_{2}\right]$.

based on classical platinum(II)-diamine pharmacophores. This has only yielded a few new drugs with a clinical advantage over the parent compound. Therefore, new methods are being adopted to explore other available platinumrelated compounds. This is centered around platinum(IV) complexes, whose anticancer properties have been recognized since the last decade. ${ }^{41}$ The stability and expanded coordination sphere serve as an advantage of overcoming the challenges inherent from platinum(II) compounds. The platinum(IV) complex has six saturated coordination spheres of low spin $\mathrm{d}^{6}$ with octahedral geometries. ${ }^{41}$ This property gives them the kinetic stability over the platinum(II) complexes. ${ }^{41}$ Similarly, the cytotoxic profile of newly synthesized platinum(IV) complex in ovarian cancer cell line (TOV21G) and colon cancer cell line (HCT-116) were determined in one study. A dose- and time-dependent cytotoxicity toward the tested cell line ${ }^{42}$ was observed with the highest cytotoxic effects on TOV21G. Platinum(IV) complex had a more pronounced cytotoxicity on TOV $21 \mathrm{G}$ at a lower concentration. ${ }^{42}$ However, platinum(IV) complex and cisplatin had a similar cytotoxic effect on the HCT-116 cell line. ${ }^{42}$

This study provides an opportunity for exploring cytotoxic properties of platinum(IV) complexes in the treatment of colon cancer as an alternative to platinum(II)-derived anticancer drugs. A good example of compounds under investigation is shown in Figure 4.

\section{Ruthenium complexes in cancer therapy and drug design}

For the past few decades, the use of metal-bases complexes in the treatment of cancer has been dominated by a spectrum of challenges emanating from the use of platinum complexes and platinum-derived drugs in clinical practice. While it is virtually impossible to deny the success of platinum drugs in chemotherapy, ${ }^{43}$ it is however important to note its limitation such as drug resistance, limited spectrum of activity and worsening side effects. ${ }^{43}$ To surmount these challenges, efforts have been made to critically consider 
other metal-based complexes with cytotoxic properties, such as ruthenium, gold and iron complexes. Ruthenium compounds developed for this purpose are known to cause fewer and less severe side effects. ${ }^{43}$ Ruthenium can form octahedral complexes that give opportunity for exploring more ligands compared to platinum(II) complexes that only form square planar complexes. ${ }^{43}$ The most recent approach to ruthenium drug design is the development of a ruthenium organic directing molecule (RODM). In this case, the organic molecule binds to the active site of an enzyme and the attached ruthenium ion binds to nearby residues of the same enzyme. ${ }^{43}$ The advantage of this approach is that there is a known biological target of a compound from which enzymological studies can be performed, such as studies of rate of enzyme inhibition. ${ }^{43}$

Other approaches include directed therapy and multinuclear approach. Ruthenium's ability to form multinuclear and supramolecular architecture has also been explored in drug design. This includes ruthenium cluster complexes, ruthenium DNA intercalators, and ruthenium-platinum-mixed metal compounds. ${ }^{43}$ In directed therapy, ruthenium is chemically attached to an organic compound with known biological target that directs the drug to the cells, thereby increasing the potency of the compound. The peculiarity of ruthenium as one of the least toxic metallic complexes is attributed, in part, to the ability of $\mathrm{Ru}(\mathrm{III})$ complex to mimic iron binding serum protein, thereby reducing the concentration of free plasma ruthenium and increasing the concentration that reaches the cancer cells compared to healthy cells. ${ }^{44}$ Plasma-bound ruthenium complexes possess high affinity to cancer cells with transferrin receptors; this brings about diverse pharmacodynamics differences that exist between cancerous and healthy cells ${ }^{44}$ and forms the basis of higher cytotoxicity experienced with KP1019 compared to NAMI-A (Figure 5). ${ }^{44}$

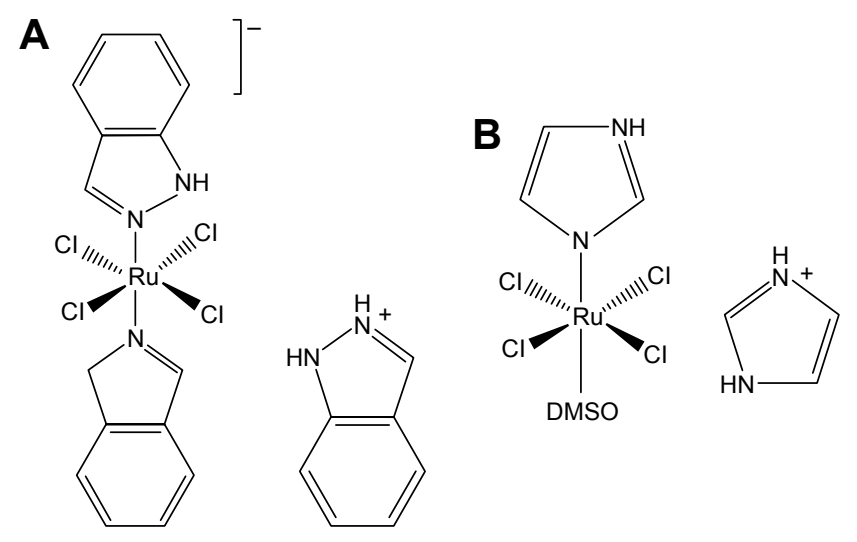

Figure 5 The structure of KPIOI9 (A) and NAMI-A (B). Abbreviation: DMSO, dimethyl sulfoxide.
The proposed transport mechanism of Ru(III) involves both passive diffusion and transferrin-dependent mechanism. ${ }^{45}$ In addition, the reduction of $\mathrm{Ru}$ (III) complex to $\mathrm{Ru}$ (II) following the cellular uptake of the former could also play an important role. ${ }^{45}$ However, research evidence has linked the cytotoxic effect of ruthenium to $\mathrm{Ru}(\mathrm{II})$-arene complexes. ${ }^{44}$

$\mathrm{Ru}(\mathrm{II})$-arene complexes incorporated into amphiphilic 1,3,5-triaza-7-phosphaadamantane (PTA) ligand, ie, $\mathrm{Ru}\left(\eta^{6}\right.$ toluene)-(PTA)Cl ${ }_{2}$, RAPTA-T, Ru( $\eta^{6}-p$-cymene)(PTA) $\mathrm{Cl}_{2}$ and RAPTA-C, exhibit low toxicity in $v^{2} \mathrm{vo}^{44}$ and are not cytotoxic, but demonstrate relevant antitumor properties (Figure 6). ${ }^{44}$ RAPTA-C selectively binds to histone protein core in chromatin, ${ }^{46}$ resulting into aquation of chloride ligands, ${ }^{44}$ and translates to mild growth inhibition on primary tumors in vivo. ${ }^{47}$ The combination of RAPT-A compounds gives unique effects, and when applied in combination with other drugs, RAPTA-C (Figure 6) produces efficient inhibition of tumor growth at very low doses without toxic side effects. ${ }^{44}$ Anticancer activities of ruthenium complexes are summarized in Table 1.

Other ruthenium complexes that are recently synthesized and show the cytotoxic effect on the cancer cell lines include the following:

- Cyclometalated ruthenium compounds: In an attempt to provide the best alternative to the platinum compounds and other metallo-tumor drugs, many approaches to the design of anticancer drugs have been adopted. One such approach is the design of cyclometalated ruthenium compound with cytotoxic properties. ${ }^{48}$ In a recent study, the cytotoxic effect of four Ru(II) dyes incorporated to the cyclometalated ligand phpy-(deprotonated 2-phenylpyridine) was evaluated against HeLa cells. ${ }^{48}$ In this study, the cytotoxic activity of all the compounds was similar to that of cisplatin. ${ }^{48}$ The activities of compounds were compared, compound $[\mathrm{Ru}(\mathrm{phpy})(\mathrm{bpy})-$ $($ dppn $)]+\left(4 ;\right.$ bpy $=2,2^{\prime}$-bipyridine, dppn $=$ benzo $[\mathrm{i}]$ dipyrido-[3,2-a:2', $3^{\prime}$-c]phenazine) being the most active among all, with an activity of about sixfold higher than the platinum $\operatorname{drug}^{48}$ and possessing the ability to disrupt
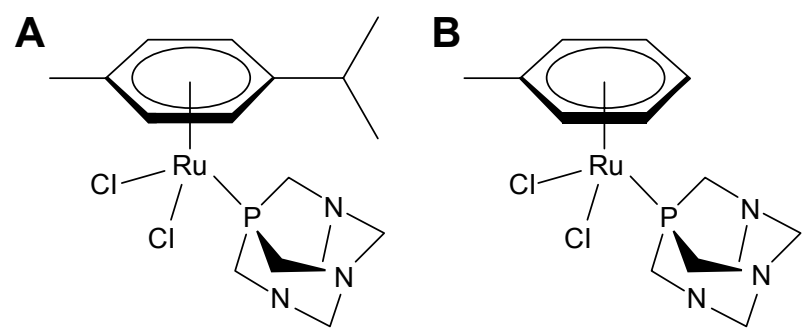

Figure 6 RAPTA-C (A) and RAPTA-T (B). 
the mitochondria membrane potential. ${ }^{48}$ Compounds such as $[\mathrm{Ru}($ phpy $)(\mathrm{biq}) 2]+\left(3\right.$; biq $=2,2^{\prime}$-biqinoline $)$ have absorption of $640 \mathrm{~nm}$, which shows a profound activity upon irradiation with $633 \mathrm{~nm}$ light. ${ }^{48}$ Based on this finding, it was concluded that coordinatively saturated cyclometalated $\mathrm{Ru}$ dyes are potential class or family of the new metal-based anticancer compounds. ${ }^{48}$

- Half-sandwiched Ru(II) compounds containing 5-fluorouracil (FU) derivatives: Combination of two or more multifunctionality groups brings into play different properties of compounds ${ }^{49}$ this is a popular strategy adopted in the design of new therapeutics. ${ }^{49}$ The use of 5-FU in the treatment of cancer has been associated with strong toxicities to gastric system, intestinal mucosa and bone marrow. ${ }^{49}$ Thus, attempts are made to improve anticancer property and minimize its side effects by exploiting other prodrugs. ${ }^{49}$ In line with this, respective advantages of $\mathrm{Ru}(\mathrm{II})$ compound and 5-FU ${ }^{50}$ can be explored and the combination results in synergistic action. ${ }^{50}$ Half-sandwiched ruthenium-arene complexes allow the introduction of numerous biologically active groups; ${ }^{49,51}$ this way many ligands can be introduced into the drug either to improve the spectrum of activity against the cancer cells or to modify the pharmacokinetic profile of the drugs. In a recent study, two novel coordination compounds of half-sandwiched $\mathrm{Ru}(\mathrm{II})$ containing 2-(5-FU)-yl- $N$-(pyridyl)-acetamide were synthesized. ${ }^{49}$ The result from DNA intercalation binding reveals that the compounds exhibit activity on DNA, ${ }^{49}$ which may be interpreted as being the cytotoxic effect on cancer cells.

\section{Titanocenes}

Titanocenes are a class of metal-based cytotoxic agents with a distinct mechanism of action and spectrum of activity from platinum complexes. ${ }^{52}$ Studies have shown that titanocene C [bis-( $N, N$-dimethylamino-2( $N$-methylpyrrolyl)-methylcyclopentadienyl) titanium(IV) dichloride] inhibits the proliferation of human tumor cell lines with a mean $\mathrm{IC}_{50}$ value of $48.3 \pm 32.5 \mu \mathrm{M}$. The activity against SCLC was more profound with a profile different from cisplatin. ${ }^{52}$ Both titanocenes $\mathrm{C}$ and $\mathrm{Y}$ have little or no cross-resistance to cisplatin and oxaliplatin invariant HL-60 cell lines. Titanocene $\mathrm{C}$ is particularly favored in the induction of cell cycle arrest at G1/0-S interphase..$^{52}$ In a related development, the cytotoxic effect and mechanism of action of titanocene difluoride in ovarian cancer were evaluated. ${ }^{53}$ In this study, three titanocene difluoride compounds were used, two of which bore carbohydrate moiety ( $\alpha$-D-ribofuranos-5-yl) and one had no substitution. ${ }^{53}$ In contrast to the mechanism of action of cisplatin that involves DNA damage, activation of p53 protein and induction of apoptosis, ${ }^{44}$ the result from this study shows that the mechanism of action of titanocene difluoride derivatives is mediated via the endoplasmic reticulum stress pathway and autophagy. ${ }^{53}$ In conclusion, the authors stated that the cytotoxic effects of titanocene difluoride are comparable to that of cisplatin and are more effective in cisplatin resistance cell line and therefore recommends that these compounds be considered as potential agents in the management of cisplatin resistance cases. ${ }^{53}$

\section{Anticancer properties of copper complexes}

Copper complexes exhibit cytotoxic properties with the mechanism of action different from that of the clinically used platinum compound cisplatin. ${ }^{54}$ A spectrum of activities varies among these compounds, depending on the type of ligand attached to the simple copper complex. Cytotoxic effects of copper-based complexes have been investigated based on the assumption that endogenous copper may be less toxic for normal cells relative to cancer cells. ${ }^{55}$ The situation is entirely different; copper can undergo redox activity and competitively bind to the site that could otherwise be occupied by other metals. ${ }^{55}$ Copper is an essential cellular element necessary for many biological pathways. It is also a cofactor in enzyme catalytic processes. ${ }^{55}$ The role of copper in angiogenesis has been a subject of controversy; generally, the role of metals in this process is still under scrutiny. ${ }^{55}$ However, copper complexes are known to mimic superoxide dismutase (SOD), ${ }^{56}$ an important antioxidant enzyme that protects cells from harmful radical superoxide through its dismutation to nontoxic molecules. ${ }^{56}$ They are present in almost all living organism. ${ }^{56}$ The native SOD is a natural scavenger of free radicals that work very efficiently in the body; ${ }^{56}$ therefore, in the presence of an imbalance between the generation of free radicals and the concentration of dismutation enzymes, ${ }^{56}$ a low molecular weight mimic of antioxidant enzymes, especially SOD, with good scavenging activity is required. ${ }^{56}$ Copper complexes, particularly of a low molecular weight, are indicated, since they are good mimics of SOD.

It has been reported that a mixture of copper salt with dithiocarbamates (DTCs) and CQ binds spontaneously to cellular copper to form a proteasome and an apoptosis inducer. ${ }^{55}$ Recently, copper(II) complex $\left[\mathrm{Cu}\left(\mathrm{C}_{20} \mathrm{H}_{22} \mathrm{NO}_{3}\right)_{2}\right] \cdot \mathrm{H}_{2} \mathrm{O}$ was synthesized and cytotoxic activity evaluated ${ }^{57}$ The complex was investigated for its interaction with calf thymus DNA 
and bovine serum albumin using spectroscopic methods. The results revealed that the binding mechanism is a static quenching process. ${ }^{57}$ The in vitro cytotoxic evaluation study was conducted using MTT assay, and the result revealed that a copper complex exhibited enhanced cytotoxicity, high selectivity and dose-dependent cytotoxicity. ${ }^{57}$

In a related development, four novel mononuclear Schiff base copper(II) complexes were synthesized and characterized by $\mathrm{X}$-ray crystallography, ${ }^{58}$ which included $[\mathrm{Cu}(\mathrm{L})$ $(\mathrm{OAc})] \cdot \mathrm{H}_{2} \mathrm{O},\left[\mathrm{Cu}(\mathrm{HL})\left(\mathrm{C}_{2} \mathrm{O}_{4}\right)(\mathrm{EtOH})\right] \cdot \mathrm{EtOH},[\mathrm{Cu}(\mathrm{L})(\mathrm{Bza})]$ and $[\mathrm{Cu}(\mathrm{L})(\mathrm{Sal})](\mathrm{HL}=1-(2-(2-h y d r o x y p r o p y l)($ aminoethyl) (imino)(methyl)naphthalene-2-ol), Bza = benzoic acid and $\mathrm{Sal}=$ salicylic acid). Antiproliferative effects of these complexes were evaluated. The result showed that all the four complexes demonstrated good cytotoxicity against cancer cell lines. ${ }^{58}$ Complexes that had salicylate attached to them as an auxiliary ligand showed better anticancer activity relative to the others. ${ }^{58}$ It was suggested that the enhanced activity of complex with the highest activity may be due to the presence of a Schiff base complex and a nonsteroidal anti-inflammatory drug that might have contributed to the process of cell death. ${ }^{58}$

\section{Gold complexes in cancer therapy}

The cytotoxic property of gold complexes has attracted attention recently. This may not be unconnected to the various level of challenges witnessed with the clinical use of platinum compounds. Gold(III) complexes are an emerging class of metal complexes with potential antitumor properties alternative to cisplatin. This is mainly due to their outstanding cytotoxic properties exhibited through non-cisplatin antitumor mechanism. The main objective of designing these drugs is to have a product that is very effective, less toxic and selectively binds to the active site of enzymes. ${ }^{59}$ The potential of selectivity of gold(III) complexes to thiol-containing enzymes such as thioredoxin reductase (TrxR) makes it an attractive probe in designing compounds that can selectively bind to residues in the active site of the enzyme.

Many forms of gold(III) complexes have been synthesized, and the anticancer activity has been evaluated against cancer cell lines. In most cases, the ligands are either $\mathrm{Cl}$, $\mathrm{Br}, \mathrm{S}$ or P. Other forms of gold(III) complexes have also been synthesized with proven cytotoxicity. ${ }^{60}$ Most of the reported cytotoxic gold(III) complexes have a profound effect on cisplatin-resistant cell lines. ${ }^{59}$ In a recent study, the cytotoxic effect of an organometallic titanocene-gold compound $\left[\left(\eta-\mathrm{C}_{5} \mathrm{H}_{5}\right)_{2} \mathrm{Ti}\left\{\mathrm{OC}(\mathrm{O}) \mathrm{CH}_{2} \mathrm{PPh}_{2} \mathrm{AuCl}\right\}_{2}\right]$ was evaluated in vitro against prostate and renal cell lines as potential chemotherapeutics in renal cancer. ${ }^{61}$ The result showed that the compound acts synergistically because the resulting cytotoxic effect is more pronounced when compared to monometallic titanocene dichloride and gold(I) [\{HOC(O) $\left.\left.\mathrm{RPPh}_{2}\right\} \mathrm{AuCl}\right]\left(\mathrm{R}=-\mathrm{CH}_{2}-6,-4-\mathrm{C}_{6} \mathrm{H}_{4}-7\right)$ in renal cancer cell lines. ${ }^{61}$

\section{TrxR: a target for gold(III) complex}

The binding of inhibitors (drugs) to the active site of the enzyme depends on the type of residues (amino acids) on the catalytic site. The catalytic residues are highly specific for certain compounds. These characteristics provide a platform for designing a compound that can specifically target certain residues, resulting in ligand-residue interaction. Since some enzymes possess more than one binding site (binding pocket), such binding sites can be filtered to get the best out of many. The relationship termed as intimacy exists between the best binding site and the compounds.

Metal-based compounds bind to specific residues, most of which are involved in enzyme catalysis. The binding of metal-based complexes to these residues results in alteration of cellular processes and consequently cell death (apoptosis). ${ }^{62}$ For example, gold(III) complexes bind to TrxR. ${ }^{62}$ The catalytic residues on this enzyme are located between two chains, with each chain contributing to the binding of gold(III) complexes. Other binding pockets have been identified in the same enzyme with less binding affinity. Figure 7 depicts the catalytic residues in TrxR.

\section{Silver complexes in cancer therapy}

Silver complexes have been known for a long time for their antimicrobial activities ${ }^{63}$ and are widely used in the treatment of infected wounds and burn cases. ${ }^{63}$ In the past, silver complexes did not receive much attention compared to other metals, ${ }^{63}$ although silver complexes also demonstrated good cytotoxic activity against many cancer cell lines. ${ }^{63}$ Recently, cytotoxic properties of silver(I) complexes have attracted a great deal of interest, this is because most silver(I) complexes have been found to exhibit a greater cytotoxic activity than cisplatin $^{63}$ with relatively low toxicity and greater selectivity toward cancer cells. ${ }^{63}$ In an vitro study conducted to assess the cytotoxic properties of silver(I) complexes against cancerous B16 (murine melanoma) and noncancerous 10T1/2 (murine fibroblast) cell lines, ${ }^{63}$ silver complexes containing hydroxymethylene group exhibited greater cytotoxic activity against B16 (murine melanoma) than $\mathrm{AgNO}_{3}, \mathrm{AgSD}$ and cisplatin. ${ }^{63}$ These complexes were found to exhibit relatively low toxicity against noncancerous 10T1/2 (murine 


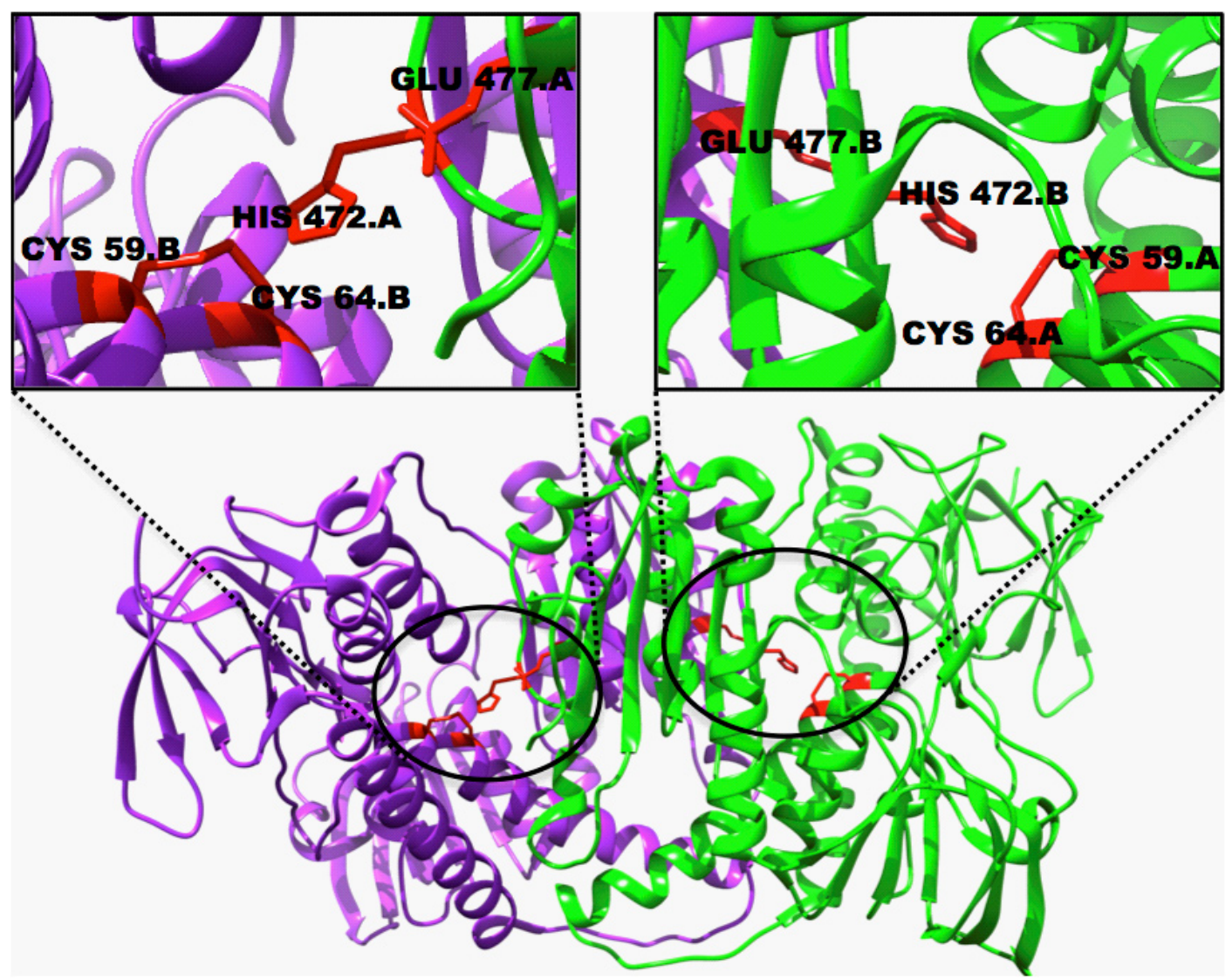

Figure 7 A 3D structure of the TrxR reductase homodimer (PDB entry 2J3N), with two chains in green and purple.

Note: The active site residues CYS 59.B, CYS 64.B, HIS 472.A and GLU 477.A represent the possible binding site for the gold(III) compounds.

Abbreviations: TrxR, thioredoxin reductase; PDB, Protein Data Bank; CYS, cysteine; HIS, histidine; GLU, glutamate.

fibroblast). ${ }^{63}$ Similarly, a study set to determine the anticancer properties of gold(I) and silver(I) N-heterocyclic carbene complexes $^{64}$ revealed that these compounds along with cisplatin exhibited similar anticancer activity upon testing on H460 lung cancer cell line. ${ }^{64}$

In a related development, silver complexes of 2,6disubstituted pyridine ligands were synthesized (Figure 8) ${ }^{65}$ The ligands and the complexes were evaluated in vitro with doxorubicin (reference compound) in hepatocellular

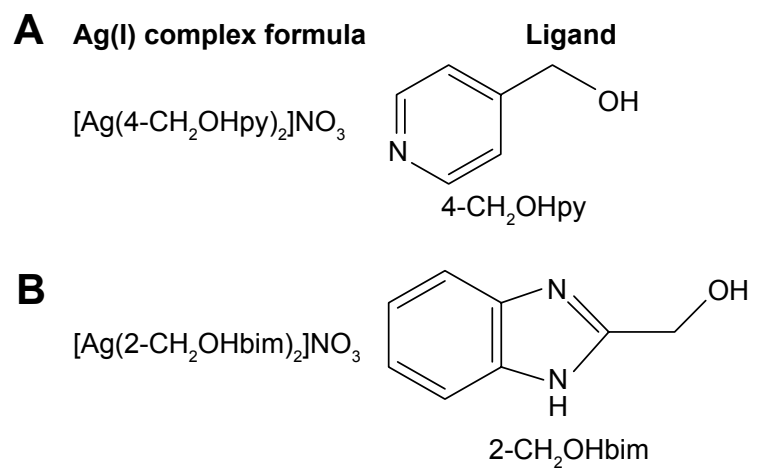

Figure 8 A and $\mathbf{B}$ are silver complexes with 2,6-disubstituted pyridine ligands. carcinoma (HepG2), lung adenocarcinoma (A549), colon carcinoma (HT29) and breast adenocarcinoma (MCF7) using the MMT method. ${ }^{65}$ All the synthesized complexes exhibited more significant activity more than the corresponding ligands, ${ }^{65}$ and most of the prepared silver complexes exhibited outstanding cytotoxic activity against tested cancer cell line compared to the doxorubicin. ${ }^{65}$ All these properties placed silver complexes as a promising metal complex to be targeted in future for chemotherapy.

\section{Metallocenes with less attention in cancer therapy}

Despite renewed attention on metal-based compounds in cancer therapy, some other compounds have received less attention in the context of cytotoxic effects on cancer cell lines. This includes zirconocene, vanadocene, niobocene and molybdocene. ${ }^{66}$ Although, zirconocenes demonstrated good antiproliferative activities against several cancer cell lines, ${ }^{66}$ such as lung adenocarcinoma, head and neck tumors, anaplastic thyroid cancer and ovarian and colon cancers, ${ }^{66}$ they need further optimization to be used as anticancer chemotherapy ${ }^{66}$ 


\section{Relative safety issues associated with metal complexes}

The role of metal-based complexes in cancer therapy cannot be overemphasized because of potential chemotherapeutic and diagnostic properties exhibited by metal-based complexes. However, since the advent of cisplatin, ${ }^{67}$ the main goal for drug design and development has been modification of toxicity profile ${ }^{67}$ that reflected relative safety of the drug, circumvention of resistance and improvement on the spectrum of activity of the metal complexes. ${ }^{67}$ Despite the major breakthrough with cisplatin in the treatment of cancer, the major challenge still remained severe side effects associated with the drug, including dose-limiting nephrotoxicity, neurotoxicity, ototoxicity and emetogenesis. ${ }^{67}$ This led to the development of carboplatin and other platinum-based cytotoxic drugs. ${ }^{67}$ Unfortunately, some platinum-based drugs developed as a result of shortcomings emanating from the clinical use of cisplatin were also associated with severe side effects that had prevented regulatory authorities from granting their marketing approval. ${ }^{68}$ Drugs in this class include JM-11 developed by Johnson Matthey, which has not been granted marketing approval because it lacked better blood and renal clearance compared to cisplatin; ${ }^{68}$ ormaplatin developed by NCI/Upjohn, which has not been granted marketing approval because of its severe and unpredictable cumulative neurotoxicity; ${ }^{68}$ zeniplatin developed by American Cyanamid, which has not been granted marketing approval because of its serious nephrotoxicity ${ }^{68}$ and spiroplatin developed by Bristol Myers, which has not been granted marketing approval because of its unpredictable renal failure. ${ }^{68}$

Similarly, gold(III) complexes have been found to exhibit toxic effects; the most adverse cases of gold complex toxicity are restricted to skin and mucous membrane as reported in case of blind clinical trial. ${ }^{69}$ In a related development, increased ceruloplasmin and copper levels in various tissues have been associated with cancer progression. ${ }^{70}$ Most of these adverse effects are dose related and can be circumvented by structural modification of the metal-based complexes to enhance selectivity and reduce unwanted effects on normal cells.

\section{Nanoparticles in cancer therapy}

Nanotechnology has greatly enhanced drug delivery system ${ }^{71}$ and to a large extent provides a means of direct drug delivery to the active site, thereby reducing the unwanted effects by limiting the drug effect to specific site and leaving other tissues untouched. In cancer medicine, nanoparticles (NPs) provide an advanced bioavailability, in vivo stability, intestinal absorption, solubility, sustained and targeted delivery and therapeutic effectiveness of several anticancer drugs. ${ }^{71}$ Most potent chemotherapeutic agents used in the treatment of cancer have a narrow therapeutic index and have been used in several tumor types $;^{71}$ however, their cytotoxic effects affect both normal and cancerous cells. ${ }^{71}$ This created a big challenge in the dosing of metal-based complexes in cancer therapy. Therefore, the opportunity provided by NPs to selectively target cancer cells and leave behind healthy cells untouched has gained interest in the design of metal-based cytotoxic drugs.

\section{Metal-based NPs}

Metal-based NPs are of different shapes and sizes and have been investigated for their role in diagnosis and drug delivery system. ${ }^{71}$ Most commonly available metal-based NPs include nickel, gold, silver, iron oxide, gadolinium and titanium dioxide. ${ }^{71}$ Metal-based NPs provide a large surface area that allowed incorporation of large drug dose. ${ }^{71}$ To improve the specificity in the diagnosis of cancers, various types of highly specific and highly sensitive NP-based optical imaging platforms are being investigated. ${ }^{72} \mathrm{NP}$-based diagnostic platforms offer a major advantage compared with other agents. They can be functionalized to specifically target tumor cells, allowing the imaging and therapeutic agent to be specifically delivered to these cells. ${ }^{72} \mathrm{NP}$ can be multifunctional and exhibits optical, magnetic and structural properties that are lacking in a single molecule. ${ }^{72}$ Since the tumor-specific targeting is achieved by conjugating the surface of NPs with a molecule or biomarker attached to the tumor cell receptor, the knowledge of tumor-specific receptors, biomarkers, homing proteins and enzymes that permit selective cellular uptake of therapeutic and diagnostic agents ${ }^{72}$ is absolutely important. In tumor targeting and conjugation, some molecules and biomarkers are precisely used. This include peptides, proteins, nucleic acid and small molecule ligands. ${ }^{72}$ It is possible to achieve a synergistic effect by conjugating multifunctional NP with different peptides and loading it with multidrug regimens ${ }^{72}$ thereby reducing the fraction of each drug in the combination.

\section{Selected targets in anticancer drug design}

Platinum complexes are widely used anticancer agents. Their use is primarily based on the pharmacological properties of cisplatin, ${ }^{73}$ which acts as a model for the design of other metal-based compounds for use in cancer therapy. ${ }^{73}$ Since all clinically utilized platinum compounds share the same 
mechanism of action, ${ }^{73}$ many researchers are now seeking to make increasingly drastic measures to the general molecular framework shared by these compounds to achieve a novel mechanism of cell death. ${ }^{44}$ Most of the research in this field is tailored toward ligand substitution method. This way, platinum-based compounds with different rates of substitution reactions at the central atom in the biological system can be developed..$^{73}$ These drugs are designed to have superior anticancer activity even in cisplatin-resistant cases and improved patient compliance. The current areas of interest in cytotoxic drug design include the following:

- Targeting of sugar: One of the major characteristics of the cancer cells is indiscriminate cell division. This occurs only in cancer cells relative to normal cells as a result of the continued supply of nutrients necessary for their metabolic process, particularly glucose, for survival. ${ }^{74}$ The need for glucose is further aggravated by the altered metabolic states in which many cancer cells exist. ${ }^{75}$ In line with this, a facet of biosugar can be exploited for drug targeting because of enhanced uptake of glucose by cancer cells. ${ }^{75}$ For example, $2 \alpha \alpha, 3$-diaminosugars complexes analogous to oxaliplatin were investigated and found to have promising activity. ${ }^{30}$ Several other prospective platinum-based compounds complexed with glucose were also investigated with seemingly promising results. ${ }^{30}$

- Targeting of steroid: Sex hormones such as testosterone and estrogen play a vital role in drug targeting. In this case, incorporation of steroidal units into nonliving group ligand is important; as a result, platinum complex is directed by its targeting unit (steroidal unit) to the tissues expressing a similar steroidal receptor. ${ }^{30}$ For instance, estrogen receptor (ER) is a known drug target because of high expression of this protein on the surfaces of some cancer cells, particularly in breast cancer. ${ }^{30}$ With the progression of research in this field, another ER has been discovered in addition to a prominent ER, designated as ER $\alpha$. This ER is termed as ER $\beta .{ }^{76}$ It has been documented that the ER $\beta$ may even play a more important role by exhibiting antiangiogenic and antiproliferative properties. ${ }^{76}$ The linkage of steroidal unit capable of interacting with the ER to a platinum center can influence the anticancer activity by interfering with biological functions of the receptor or by permitting enhanced uptake of platinum complexes. ${ }^{30}$ This way the DNA platination is increased with a resultant higher chance of apoptotic cell death. ${ }^{30}$ Just as ER targets platinum to the cancer cells expressing ER receptors, testosterone can target platinum to cancer cells expressing androgen receptor (AR)..$^{30,63}$
- Targeting of bile acid: Bile acids are steroidal in nature and have been conjugated to platinum complexes ${ }^{30}$ in an effort to deliver compounds directly to the liver cells since a number of transport proteins that take up bile salt from blood are expressed on the hepatic epithelial cells. ${ }^{30}$ Several efforts have been made to conjugate platinum complexes to the bile acid in different manners, and the resultant complex seems to have promising anticancer activity. ${ }^{30}$ For example, a bile acid chelated to dicarboxylate motif bound to a cis-diammineplatinum(II) fragment was explored as an orally administered anticancer agent. ${ }^{30}$ Preliminary in vitro assay revealed activity in cultured murine hepatoma cells, ${ }^{30}$ and further research on a syngeneic orthotopic rat model of hepatocellular carcinoma confirmed that the complex had antitumor activity. ${ }^{30}$

- Targeting of related steroids: The translocator protein (TSPO) commonly known as peripheral benzodiazepine is known to regulate the transport of cholesterol and synthesis of steroids. ${ }^{77}$ This protein has been suggested to be an important target in cancer treatment since it is overexpressed in numerous tumor cells. ${ }^{77}$ Chelated platinum(II) complexes with bidentate thiazolylimidazopyridine are reported to interact strongly with this receptor. ${ }^{30}$

- Targeting of folate: Folate is an important carbon source for many cellular pathways, including DNA, RNA, protein methylation and DNA synthesis. ${ }^{78}$ Cancer cell growth is rapid with enhanced folate uptake. The role of folate in all these processes could conceivably be used as a baseline for drug targeting. ${ }^{78}$ However, there is a limitation to the use of folate as a targeting agent of platinum complex. An early study of the interaction of cisplatin with cellular folates suggests that it would not be able to operate as a cytosolic agent in a manner analogous to cisplatin. ${ }^{79}$ However, researchers are not relenting in their effort to understand the potential of folate in the selective drug targeting.

- Targeting of peptide: Conjugation of platinum(II) complexes to the peptide results in the platination of complexes with anticancer activity. ${ }^{30}$ The cyclic peptide c(CNRGC) with Asn-Gly-Arg sequence that targets CD13 receptor is overexpressed on the surface of certain cancer cells. ${ }^{80}$ The target complex is more toxic to prostate cancer cells expressing CD13 than non-targeted carboplatin, ${ }^{30}$ and the competition assays confirmed that the complex is taken up via the interaction with CD13. ${ }^{30}$ Many forms of platinum complexes conjugated with peptides have been screened against cancer cell lines, and a reasonable number of them exhibit a promising anticancer activity. 


\section{Conclusion}

Since the discovery of cisplatin, a great deal of research has been conducted in the therapeutic application of metalbased complexes. These compounds exhibit ambivalent dispositions: some are associated with induction and progression of cancers, some have demonstrated efficacy in cancer treatment and some display both properties. Despite the challenges emanating from the clinical use of platinum compounds, there is a growing demand for metal-based compounds in cancer therapy. This may be due to the scourge of cancer and, to the greater extent, the level of in vitro cytotoxic effects exhibited by metal-based compounds, particularly those that have been synthesized recently. There is excitement among some researchers in this field that cancer cells can directly be targeted using a different approach of drug design as highlighted in this study. This development put to rest the fear of toxicity associated with many organometallics since the drugs are directly delivered to the cancer cells leaving behind healthy cells unharmed. However, the pharmacokinetic profile of most of these drugs is yet to be ascertained in the human system, but keeping our hope alive that designing a-metal-based compound to selectively target cancer cells is a major breakthrough in this field of research. Another approach in the field of anticancer drug design is the use of NPs to target the biomolecules. Such a method ensures that drugs are delivered to specific cancer cells. To this extent, the concept of selective targeting remains the hope of the future in developing therapeutics that would selectively target cancer cells, leaving behind healthy cells unharmed.

\section{Acknowledgment}

The authors acknowledge the School of Health Science, University of KwaZulu-Natal, Westville campus, for financial assistance.

\section{Disclosure}

The authors report no conflicts of interest in this work.

\section{References}

1. Norn S, Permin H, Kruse E, Kruse PR. Mercury a major agent in the history of medicine and alchemy. Dan Medicinhist Arboq. 2008; 36:21-40.

2. Agnew J. Medicine in the Old West: A History, 1850-1900. Jefferson, NC: McFarland; 2010.

3. Waxman S, Anderson KC. History of the development of arsenic derivatives in cancer therapy. Oncologist. 2001;6(suppl 2):3-10.

4. Fricker SP. Medical uses of gold compounds. Gold Bull. 1996;29(2): 53-60.

5. Jungwirth U, Kowol CR, Keppler BK, Hartinger CG, Berger W, Heffeter P. Anticancer activity of metal complexes: involvement of redox processes. Antioxid Redox Signal. 2011;15(4):1085-1127.
6. Nicolini M. Platinum and Other Metal Coordination Compounds in Cancer Chemotherapy. Vol. 54. New York: Springer; 1997.

7. Ji H-F, Li X-J, Zhang H-Y. Natural products and drug discovery. Can thousands of years of ancient medical knowledge lead us to new and powerful drug combinations in the fight against cancer and dementia? EMBO Rep. 2009;10(3):194-200.

8. Frezza M, Hindo S, Chen D, et al. Novel metals and metal complexes as platforms for cancer therapy. Curr Pharm Des. 2010;16(16): $1813-1825$.

9. Bruijnincx P, Sadler P. New trends for metal complexes with anticancer activity. Curr Opin Chem Biol. 2008;12(12):197-206.

10. Mourino V, Cattalini JP, Boccaccini AR. Metallic ions as therapeutic agents in tissue engineering scaffolds: an overview of their biological applications and strategies for new developments. $J R$ Soc Interface. 2012;9(68):401-419.

11. Benedetti BT, Peterson EJ, Kabolizadeh P, Martínez A, Kipping R, Farrell NP. Effects of noncovalent platinum drug-protein interactions on drug efficacy: use of fluorescent conjugates as probes for drug metabolism. Mol Pharm. 2011;8(3):940-948.

12. Bhargava A, Vaishampayan UN. Satraplatin: leading the new generation of oral platinum agents. Expert Opin Investig Drugs. 2009;18(11): $1787-1797$.

13. Milacic V, Fregona D, Dou QP. Gold complexes as prospective metalbased anticancer drugs. Histo Histopathol. 2008;23(1):101-108.

14. Bindoli A, Pia M, Scutari G, Gabbiani C, Casini A, Messori L. Thioredoxin reductase: a target for gold compounds acting as potential anticancer drugs. Coord Chem Rev. 2009;253:1692-1707.

15. Kostova I. Ruthenium complexes as anticancer agents. Curr Med Chem. 2006;13(9):1085-1107.

16. Karlenius TC, Tonissen KF. Thioredoxin and cancer: a role for thioredoxin in all states of tumor oxygenation. Cancers (Basel). 2010; 2(2):209-232.

17. Arredondo M, Núñez MT. Iron and copper metabolism. Mol Aspects Med. 2005;26(4-5):313-327.

18. Balamurugan K, Schaffner W. Copper homeostasis in eukaryotes: teetering on a tightrope. Biochim Biophys Acta. 2006;1763(7):737-746.

19. Go YM, Jones DP. Redox compartmentalization in eukaryotic cells. Biochim Biophys Acta. 2008;1780(11):1273-1290.

20. Gupte A, Mumper RJ. Elevated copper and oxidative stress in cancer cells as a target for cancer treatment. Cancer Treat Rev. 2009;35(1): $32-46$.

21. Hentze MW, Muckenthaler MU, Andrews NC. Balancing acts: molecular control of mamalian iron metabolism. Cell. 2004;117(3):285-297.

22. Pattan SR, Pawar SB, Vetal SS, Gharate UD, Bhawar SB. The scope of metal complexes in drug design - a review. Indian Drugs. 2012; 49(11):5-12.

23. Haas KL, Franz KJ. Application of metal coordination chemistry to explore and manipulate cell biology. Chem Rev. 2010;109(10): 4921-4960.

24. Yan YK, Melchart M, Habtemariam A, Sadler PJ. Organometallic chemistry, biology and medicine: ruthenium arene anticancer complexes. Chem Commun. 2005;14(38):4764-4776.

25. Salga MS, Ali HM, Abdulla MA, Abdelwahab SI. Acute oral toxicity evaluations of some zinc(II) complexes derived from 1-(2Salicylaldiminoethyl)piperazine schiff bases in rats. Int $J \mathrm{Mol} S \mathrm{Sci}$. 2012;13(2):1393-1404.

26. Florea A-M, Büsselberg D. Cisplatin as an anti-tumor drug: cellular mechanisms of activity, drug resistance and induced side effects. Cancers (Basel). 2011;3(1):1351-1371.

27. Monneret C. Platinum anticancer drugs. From serendipity to rational design. Ann Pharm Fr. 2011;69(6):286-295.

28. Chan BA, Coward JIG. Review article chemotherapy advances in small-cell lung cancer. J Thorac Dis. 2007;5(5):S565-S578.

29. Uehara T, Yamate J, Torii M, Maruyama T. Comparative nephrotoxicity of cisplatin and nedaplatin: mechanisms and histopathological characteristics. J Toxicol Pathol. 2011;24(2):87-94. 
30. Johnstone TC, Suntharalingam K, Lippard SJ. The next generation of platinum drugs: targeted $\mathrm{Pt}(\mathrm{II})$ agents, nanoparticle delivery, and $\mathrm{Pt}(\mathrm{IV})$ prodrugs. Chem Rev. 2016;116(5):3436-3486.

31. Peng Y, Liu YE, Ren XC, et al. A phase I clinical trial of dose escalation of lobaplatin in combination with fixed - dose docetaxel for the treatment of human solid tumours that had progressed following chemotherapy. Oncol Lett. 2015;9(1):67-74.

32. Shah N, Dizon DS. New-generation platinum agents for solid tumors. Future Oncol. 2009;5(1):33-42.

33. Karlin DA, Breitz HB, Weiden PI. Use of picoplatin to treat colorectal cancer. United States Patent Application Publication. 2012;1:1-19.

34. Wheate NJ, Walker S, Craig GE, Oun R. The status of platinum anticancer drugs in the clinic and in clinical trials. Dalton Trans. 2010; 39(35):8113-8127.

35. Liu D, Poon C, Lu K, He C, Lin W. Self-assembled nanoscale coordination polymers with trigger release properties for effective anticancer therapy. Nat Commun. 2014;25(5):4182.

36. Apps MG, Choi EH, Wheate NJ. The state-of-play and future of platinum drugs. Endocr Relat Cancer. 2015;22(4):R219-R233.

37. Ohi H, Ashizaki M, Obata M, et al. Syntheses, characterization, and antitumor activities of platinum (II) and palladium (II) complexes with sugar-conjugated triazole ligands. Chem Biodivers. 2012;9(9): 1903-1915.

38. Mi Q, Ma Y, Gao X, et al. 2-Deoxyglucose conjugated platinum (II) complexes for targeted therapy: design, synthesis, and antitumor activity. J Biomol Struct Dyn. 2015;0:1-12.

39. Patra M, Johnstone TC, Suntharalingam K, Lippard SJ. A potent glucose-platinum conjugate exploits glucose transporters and preferentially accumulates in cancer cells. Angew Chem Int Ed Engl. 2016; 55(7):2550-2554.

40. Ellena J, Gozzo C, Cominetti MR, et al. Chiral platinum(II) complexes featuring phosphine and chloroquine ligands as cytotoxic and monofunctional DNA-binding agents. Inorg Chem. 2015;54(24):11709-11720.

41. Timothy C, Wilson JJ, Lippard SJ, Link C. Monofunctional and higher-valent platinum anticancer agents. Inorg Chem. 2013;52(21): 12234-12249.

42. Milovanovic M, Volarevic V. Cytotoxic properties of platinum (IV) and dinuclear platinum (II) complexes and their ligand substitution reactions with guanosine. Transition Metal Chem. 2012;37(5):481-488.

43. Page S. Ruthenium compounds as anticancer agents. Educ Chem. 2012;10:26-29.

44. Allardyce CS, Dyson PJ. Metal-based drugs that break the rules. Dalton Trans. 2016;45(8):3201-3209.

45. Webb MI, Walsby CJ. Albumin binding and ligand-exchange processes of the Ru(III) anticancer agent NAMI-A and its bis-DMSO analogue determined by ENDOR spectroscopy. Dalton Trans. 2015; 44(40):17482-17493.

46. Babak MV, Meier SM, Huber KVM, et al. Target profiling of an antimetastatic RAPTA agent by chemical proteomics: relevance to the mode of action. Chem Sci. 2015;6:2449-2456.

47. Weiss A, Ding X, van Beijnum JR, et al. Rapid optimization of drug combinations for the optimal angiostatic treatment of cancer. Angiogenesis. 2015;18(3):233-244.

48. Peña B, David A, Pavani C, et al. Cytotoxicity studies of cyclometallated ruthenium(II) compounds: new applications for ruthenium dyes. Organometllics. 2014;33(5):1100-1103.

49. Li Z, Hou Y, Qin D, Jin Z, Hu M. Two half-sandwiched ruthenium (II) compounds containing 5-fluorouracil derivatives: synthesis and study of DNA intercalation. PLoS One. 2015;10(3):e0120211.

50. Liu KG, Cai XQ, Li XC, Qin DA, Hu ML. Arene-ruthenium(II) complexes containing 5-fluorouracil-1-methyl isonicotinate: synthesis and characterization of their anticancer activity. Inorganica Chim Acta. 2012;388:78-83.

51. Motswainyana WM, Ajibade PA. Anticancer activities of mononuclear ruthenium (II) coordination complexes. Adv Chem. 2015; 2015(2015):1-21.
52. Olszewski U, Claffey J, Hogan M, et al. Anticancer activity and mode of action of titanocene C. Invest New Drugs. 2011;29(4):607-614.

53. Koubkova L, Vyzula R, Karban J, et al. Evaluation of cytotoxic activity of titanocene difluorides and determination of their mechanism of action in ovarian cancer cells. Invest New Drugs. 2015;33(5): 1123-1132.

54. Palma G, D'Aiuto M, Rea D, et al. Organo-metallic compounds: novel molecules in cancer therapy. Biochem Pharmacol Open Access. 2014;13(13):1603-1615.

55. Santini C, Pellei M, Gandin V, Porchia M, Tisato F, Marzano C. Advances in copper complexes as anticancer agents. Chem Rev. 2014; 114(1):815-862.

56. Khalid H, Hanif M, Hashmi MA, Mahmood T, Ayub K, Monim-U1Mehboob M. Copper complexes of bioactive ligands with superoxide dismutase activity. Mini Rev Med Chem. 2013;13(13):1944-1956.

57. Shokohi-pour Z, Chiniforoshan H, Momtazi-borojeni AA, Notash B. A novel Schiff base derived from the gabapentin drug and copper (II) complex: synthesis, characterization, interaction with DNA/protein and cytotoxic activity. J Photochem Photobiol B. 2015;162:34-44.

58. Lian W-J, Wang X-T, Xie C-Z, et al. Mixed-ligand copper Schiff base complexes: the role of the co-ligand in DNA binding, DNA cleavage, protein binding and cytotoxicity. Dalton Trans. 2016;45(22): 9073-9087.

59. Zou T, Ching A, Lum T, Lok C-N, Zhang J-J, Che C-M. Chemical biology of anticancer gold(III) and gold(I) complexes. Chem Soc Rev. 2015;44:8786-8801.

60. da Silva Maia PI, Deflon VM, Abram U. Gold(III) complexes in medicinal chemistry. Future Med Chem. 2014;6(13):1515-1536.

61. Ferna J, Elie BT, Sulzmaier FJ, Sanau M, Ramos JW, Contel M. Organometallic titanocene-gold compounds as potential chemotherapeutics in renal cancer. Study of their protein kinase inhibitory properties. Organometallics. 2014;33(42):6669-6681.

62. Das SK, Dinda J. Novel gold(I) - and gold(III) - N-heterocyclic carbene complexes: synthesis and evaluation of their anticancer properties. Organometallics. 2014;33(10):2544-2548.

63. Kalinowska-Lis U, Felczak A, Checinska L, et al. Antibacterial activity and cytotoxicity of silver(I) complexes of pyridine and (Benz)imidazole derivatives. X-ray crystal structure of $[\mathrm{Ag}(2,6-\mathrm{di}(\mathrm{CH}(2) \mathrm{OH}) \mathrm{py})(2)]$ NO(3). Molecules. 2015;21(2):87.

64. Siciliano TJ, Deblock MC, Hindi KM, et al. Synthesis and anticancer properties of gold(I) and silver(I) N-heterocyclic carbene complexes. J Organomet Chem. 2011;696(5):1066-1071.

65. Ali KA, Abd-Elzaher MM, Mahmoud K. Synthesis and anticancer properties of silver(I) complexes containing 2,6-Bis(substituted)pyridine derivatives. Int J Med Chem. 2013;2013:256836.

66. Martins P, Marques M, Coito L, Pombeiro AJ, Baptista PV, Fernandes AR. Organometallic compounds in cancer therapy: past lessons and future directions. Anticancer Agents Med Chem. 2014;14(19):1199-1212.

67. Farrell N. Transition metal complexes as drugs and chemotherapeutic agents. Met Complexes Drugs Chemother Agents. 1989;11:809-840.

68. Wheate NJ, Walker S, Craig GE, Oun R. The status of platinum anticancer drugs in the clinic and in clinical trials. Dalton Trans. 2012; 39(35):8113-8127.

69. Uversky VN, Kretsinger RH, Permyakov EA. Encyclopedia of Metalloproteins. Vol. 1. New York: Springer; 2013:1-89.

70. Iakovidis I, Delimaris I, Piperakis SM. Copper and its complexes in medicine: a biochemical approach. Mol Biol Int. 2011;2011: 594529.

71. Díaz MR, Vivas-Mejia PE. Nanoparticles as drug delivery systems in cancer medicine: emphasis on RNAi-containing nanoliposomes. Pharmaceuticals (Basel). 2013;6(11):1361-1380.

72. Ventola CL. The nanomedicine revolution: part 2: current and future clinical applications. $P$ T. 2012;37(10):582-591.

73. Bergamo A, Sava G. Linking the future of anticancer metal-complexes to the therapy of tumour metastases. Chem Soc Rev. 2015;44(24): 8818-8835. 
74. Laquintana V, Trapani A, Denora N, Wang F, Gallo JM, Trapani G. New strategies to deliver anticancer drugs to brain tumors. Expert Opin Drug Deliv. 2009;6(10):1017-1032.

75. Coller HA. Is cancer a metabolic disease? Am J Pathol. 2014; 184(1):4-17.

76. Capper CP, Rae JM, Auchus RJ. The metabolism, analysis, and targeting of steroid hormones in breast and prostate cancer. Horm Cancer. 2016;7(3):149-164.

77. Joo HK, Lee YR, Kang G, Choi S, Kim C, Ryoo S. The 18-kDa translocator protein inhibits vascular cell adhesion molecule-1 expression via inhibition of mitochondrial reactive oxygen species. Mol Cells. 2015;38(12):1064-1070.

78. Crider KS, Yang TP, Berry RJ, Bailey LB. Folate and DNA methylation: a review of molecular mechanisms and the evidence for folate's role. Adv Nutr. 2012;3(1):21-38.

79. Zwicke GL, Mansoori GA, Jeffery CJ. Targeting of cancer nanotherapeutics. Nano Rev. 2012;1:1-11.

80. Xiao YF, Jie MM, Li BS, et al. Peptide-based treatment: a promising cancer therapy. J Immunol Res. 2015;2015:761820.

81. Stefan L, Pirrotta M, Monchaud D, et al. Caffeine-based gold(I) $\mathrm{N}$ - heterocyclic carbenes as possible anticancer agents: synthesis and biological properties. Inorg Chem. 2014;53(4):2296-2303.

82. Pellei M, Gandin V, Marinelli M, et al. Synthesis and biological activity of ester- and amide-functionalized imidazolium salts and related water-soluble coinage metal N-heterocyclic carbene complexes. Inorg Chem. 2012;51(18):9873-9882.

83. Hackenberg F, Mu H, Smith R, Streciwilk W, Zhu X, Tacke M. Novel ruthenium(II) and gold(I) NHC complexes: synthesis, characterization, and evaluation of their anticancer properties. Organometallics. 2013;32(19):5551-5560.

84. Dragutan I, Dragutan V, Demonceau A. Editorial of special issue ruthenium complex: the expanding chemistry of the ruthenium complexes. Molecules. 2015;20(9):17244-17274.

85. Zhang JJ, Muenzner JK, Abu El Maaty MA, et al. A Multi-target caffeine derived rhodium(I) N-heterocyclic carbene complex: evaluation of the mechanism of action. Dalton Trans. 2016;45(33):13161.

86. Eloy L, Saker L, Poupon J, et al. Antitumor trans-N-heterocyclic carbene-amine-Pt(II) complexes: synthesis of dinuclear species and exploratory investigations of DNA binding and cytotoxicity mechanisms. J Med Chem. 2013;56(5):2074-2086.

87. El-tabl AS, El-waheed MMA, Wahba MA, El-fadl NAE. A. synthesis, characterization, and anticancer activity of new metal complexes derived from 2-Hydroxy-3-(hydroxyimino)-4-oxopentan-2-ylidene benzohydrazide. Bioinorg Chem Appl. 2015;1:2-14.

88. Pfeiffer, H. Synthesis and Biological Activity of Molybdenum Carbonyl Complexes and Their Peptide Conjugates [dissertation]. JuliusMaximilians-Universität Würzburg. 2012;6-137.
89. Carter R, Westhorpe A, Romero MJ, et al. Radiosensitisation of human colorectal cancer cells by ruthenium (II) arene anticancer complexes. Sci Rep. 2016;6:20569.

90. Raosaheb G, Sinha S, Chhabra M, Paira P. Bioorganic \& medicinal chemistry letters synthesis of novel anticancer ruthenium - arene pyridinylmethylene scaffolds via three-component reaction. Bioorg Med Chem Lett. 2016;26:2695-2700.

91. Wang Z, Qian H, Yiu S, Sun J, Zhu G. Multi-targeted organometallic ruthenium (II) - arene anticancer complexes bearing inhibitors of poly (ADP-ribose) polymerase-1: a strategy to improve cytotoxicity. J Inorg Biochem. 2014;131:47-55.

92. Rodr AM, Espino G. Derivation of structure-activity relationships from the anticancer properties of ruthenium(II) arene complexes with 2-aryldiazole ligands. Inorg Chem. 2014;53(20):11274-11288.

93. Hanif M, Nazarov AA, Hartinger CG, et al. Osmium (II)- versus ruthenium (II) - arene carbohydrate-based anticancer compounds: similarities and differences. Dalton Trans. 2010;39(31):7345-7352.

94. Maroto-Díaz M, Elie BT, Gómez-Sal P, et al. Synthesis and anticancer activity of carbosilane metallodendrimers based on arene ruthenium (II) complexes. Dalton Trans. 2016;45(16):7049-7066.

95. Mohan N, Muthumari S, Ramesh R. Ruthenium (II) complexes containing aroylhydrazone ligands. J Organomet Chem. 2016;807:45-51.

96. Millett AJ, Habtemariam A, Romero-canelo I, Clarkson GJ, Sadler PJ. Contrasting anticancer activity of half-sandwich iridium(III) complexes bearing functionally diverse 2-phenylpyridine ligands. Organometallics. 2015;34(11):2683-2694.

97. Valente A, Santos AM, Côrte-real L, et al. DNA interaction and cytotoxicity studies of new ruthenium(II) cyclopentadienyl derivative complexes containing heteroaromatic ligands. J Organomet Chem. 2014;105(2):241-249.

98. Fernandes AC, Florindo P, Pereira DM, Pedro M, Rodrigues CMP, Fátima M. Cyclopentadienyl-ruthenium (II) and iron (II) organometallic compounds with carbohydrate derivative ligands as good colorectal anticancer agents. J Med Chem. 2015;58(10):4339-4347.

99. Qamar B, Liu Z, Hands-portman I. Organometallic iridium(III) anticancer complexes with new mechanisms of action: NCI-60 screening, mitochondrial targeting, and apoptosis. Chem Biol. 2013;8(6): 1335-1345.

100. Antonarakis ES, Emadi A. Ruthenium-based chemotherapeutics: are they ready for prime time? Cancer Chemother Pharmacol. 2010; 66(1):1-9.

101. Szymański P, Fraczek T, Markowicz M, Mikiciuk-Olasik E. Development of copper based drugs, radiopharmaceuticals and medical materials. Biometals. 2012;25(6):1089-1112.
Drug Design, Development and Therapy

\section{Publish your work in this journal}

Drug Design, Development and Therapy is an international, peerreviewed open-access journal that spans the spectrum of drug design and development through to clinical applications. Clinical outcomes, patient safety, and programs for the development and effective, safe, and sustained use of medicines are the features of the journal, which

\section{Dovepress}

has also been accepted for indexing on PubMed Central. The manuscript management system is completely online and includes a very quick and fair peer-review system, which is all easy to use. Visit http://www.dovepress.com/testimonials.php to read real quotes from published authors. 